\title{
"We the People": John Locke, Collective Constitutional Rights, and Standing to Challenge Government Action
}

\section{Donald L. Doernberg $\dagger$}

The first three words of the preamble to the Constitution ${ }^{1}$ suggest one element unique to the American Revolution: its outcome was a government created by the people, not one existing independently of them or, in some respect, over them. ${ }^{2}$ Indeed, the preamble reads like a charge to the new government, as though the Framers had said "this is what you, the government, shall do," and then in the Constitution said "and here is how you shall accomplish it." The idea of popular sovereignty in the Umited States antedates the Constitution, appearing in its best known form in the Declaration of Independence's admonition that governments must be viewed as "deriving their just powers from the consent of the governed,"3 and ultimately being attributed to the influence of both John Locke $^{4}$ and Jean Jacques Rousseau. ${ }^{5}$

One problem that the American legal system has encountered is the enforcement of the limits set by the Constitution and statutes on government operation. ${ }^{6}$ Whether the government has exceeded its lawful

$\dagger$ Visiting Professor of Law, University of California, Hastings College of the Law, 1984-85; Professor of Law, Pace University. B.A. 1966, Yale University; J.D. 1969, Columbia University.

I gratefully acknowledge the thoughtful editing suggestions of Professors Burton Leiser and Donald H. Zeigler, and the research assistance of Steven Chananie, Jonathan Diamond, Veronica Hakiin, Teri Shulman, Sarah Whalen, and the staff of the Pace University Law Library.

1. U.S. ConsT. preainble:

We the People of the United States, in Order to form a more perfect Union, establish Justice, ensure domestic Tranquility, provide for the comnnon defence, promote the general Welfare, and secure the Blessings of Liberty to ourselves and our Posterity, do ordain and establish this Constitution for the United States of Anerica.

2. Alexander Hamilton, arguing that the proposed adoption of a bill of rights was unnecessary and potentially harmful, relied heavily on the nature of the new American government. "Here, in strictness, the people surrender nothing; and as they retain every thing they have no need of particular reservations." THE FEDERALIST No. 84, at 513 (A. Hainilton) (C. Rossitcr ed. 1961). He also characterized the Constitution as "professedly founded upon the power of the people, and executed by their iminediate representatives and servants." Id.

3. The Declaration of Independence para. 2 (U.S. 1776).

4. See infra note 41 .

5. J. Rousseau, The Social Contract and Discourses (D. Cress ed. 1983).

6. It is universally recognized that the United States government was intended to be one of carefully circumscribed powers, defined by enumeration. This limitation is, perhaps, most directly 
bounds is a question for the judiciary to decide, as Marbury v. Madison ${ }^{7}$ made clear. But who may ask the courts to decide? That question is ordinarily resolved by application of the doctrine of standing. ${ }^{8}$ In recent years, questions of standing have been deterinined by application of a two-part test. First, tlie court must examine whetlier tlie party seeking relief has "such a personal stake in the outcome of the controversy as to assure that concrete adverseness whicl sharpens the presentation of issues upon whicli the court so largely depends for illumination of difficult constitutional questions." Second, there must be "some connection between the official action challenged and some legally protected interest of the party challenging tliat action."10 The first part of tlie test, commonly referred to as injury-in-fact, ${ }^{11}$ is indispensable because it is viewed as part of the case-or-controversy requirement; ${ }^{12}$ hence, it is jurisdictional. ${ }^{13}$

reflected in the 10th amendment: "The powers not delegated to the United States by the Constitution, nor prohibited by it to the States, are reserved to the States respectively, or to the people." U.S. CONST. amend. $\mathrm{X}$.

7. 5 U.S. (1 Cranch) $137,177-80$ (1803).

8. The question of standing concerns whether "a party has a sufficient stake in an otherwise justiciable controversy to obtain judicial resolution of that controversy." Sierra Club v. Morton, 405 U.S. 727, 731 (1972). See generally L. TRIBE, AMERICAN ConSTITUMONAL LAw $\$ \$ 3-17$ to -29 (1978).

9. Baker v. Carr, 369 U.S. 186, 204 (1962). This first requirement, then, focuses on the party secking relief rather than on the nature of the rehief sought.

10. Jenkins v. McKeithen, 395 U.S. 411,423 (1969). The phrase "legally protected interest" has been rejected by the Court as conveying too restrictive a view of this part of the test. See infra notes 217-26 and accompanying text. But current law still requires some nexus between the challenged official activity and a legally cognizable interest of the plaintiff. As Professor Tribe has explained:

The nexus requirement bears a family resemblance to the "scope of the risk" doctrine in the law of torts. Thus, in tort law, it is not enough that the defendant's violation of the law caused injury to the plaintiff: the defendant also nust owe the plaintiff some duty. Similarly, in the federal law of standing, it is not enough that the plaintiff be injured by sone act or omission of the defendant; the defendant nust additionally have violated sone duty owed to the plaintiff. Applying this doctrine to challenges of official government action or inaction, the relevant question would not be simply whether the official or agency violated the law, but rather whether the official or agency violated any duty to the plaintiff.

L. TRIBE, supra note $8, \S 3-22$, at 98 (footnotes omitted).

11. See, e.g., Valley Forge Christian College v. Americans United for Separation of Church \& State, Inc., 454 U.S. 464, 472 (1982); Duke Power Co. v. Carolina Envtl. Study Group, Inc., 438 U.S. 59, 72-74 (1978). See generally L. TRIBE, supra note 8, § 3-20.

12. U.S. ConsT. art. IIl, $\S 2$, cl. 1.

13. The Court explained the jurisdictional nature of the injury-in-fact test in 1982:

[A]t an irreducible minimum, Art. III requires the party who invokes the court's authority to "show that he personally has suffered some actual or threatened imjury as a result of the putatively illegal conduct of the defendant," Gladstone, Realtors v. Village of Bellwood, 441 U.S. 91, 99 (1979), and that the injury "fairly can be traced to the challenged action" and "is likely to be redressed by a favorable decision," Simon v. Eastern Kentucky Welfare Rights Org., 426 U.S. 26, 38, 41 (1976). In this manner does Art. III limit the federal judicial power "to those disputes which confine federal courts to a role consistent with a systen of separated powers and which are traditionally thought to be capable of resolution through the judicial process." Flast v. Cohen, 392 U.S. [83, 97 (1968)].

Valley Forge Christian College v. Americans United for Separation of Church \& State, Inc., 454 U.S. 464, 472 (1982) (footnotes onitted). In the same opmion, the Court recognized: 
The second part of the test is commonly called the nexus requirement ${ }^{14}$ and is not constitutionally mandated. ${ }^{15}$ The nexus test, first announced in Flast v. Cohen, ${ }^{16}$ requires examination of the substantive issues raised in a case "to determine whether there is a logical nexus between the status asserted and the claim sought to be adjudicated." 17

Unfortunately, this two-part test proved extremely difficult to apply, leading the Court to observe in 1969 that "[t]he concept of standing to sue . . . 'is surrounded by the same complexities and vagaries that inhere in [the concept of] justiciability' in general." 18 The nexus requirement in particular has come under fire.

The search for nexus . . . risks begging the vital question of whether the plaintiff is truly claiming injury to his own legally protected interest or whether the plaintiff, although claiming a material injury, is in fact asserting the interests of someone else but should nonetheless be accorded surrogate standing. Even when the nexus rule does not operate to deny standing, therefore, it may entail substantial disadvantages.

Even more pointedly, the rule of nexus can induce denials of standing where a decision on the merits would be preferable. ${ }^{19}$

As a consequence, Professor Tribe has advocated dropping the nexus requirement in many circumstances, particularly where official action is

[I]t has not always been clear in the opinions of this Court whether particular features of the "standing" requirement have been required by Art. III ex proprio vigore, or whether they are requirements that the Court itself has erected and which were not compelled by the language of the Constitution.

Id. at 471 .

14. See, e.g., Duke Power Co. v. Carolina Envtl. Study Group, Inc., 438 U.S. 59, 78-81 (1978); Flast v. Cohen, 392 U.S. 83, 101-02 (1968). See generally L. TRIBE, supra note 8, § 3-22.

15. See, e.g., Duke Power Co. v. Carolina Envtl. Study Group, Inc., 438 U.S. 59, 78.81 (1978). "Unlike the 'injury in fact' requirement, the 'nexus' requirement is clearly not compelled by article III but represents only a prudential limitation upon the exercise of federal jurisdiction." L. TRIBE, supra note 8, § 3-22, at 97 n.2 (emphasis in original).

16. 392 U.S. 83 (1968). Flast was a taxpayer's challenge to government action that allegedly violated the first amendment's establishment clause.

17. Id. at 102. The nexus requirement thus stated has two components. First, the taxpayer must show a connection betwecn his status as a taxpayer and the challenged activity. Id. Taxpayer standing therefore requires a challenge to some exercise of the government's taxing power. Second, the taxpayer must show that the exercise of the taxing power violates a specific constitutional restriction on that power, rather than that the challenged activity merely exceeds a more general restriction on governmental power. Id. at 102-03.

It was unclear in Flast whether the nexus requirement applied to suits not brought by taxpayers qua taxpayers. In Linda R.S. v. Richard D., 410 U.S. 614, 618 (1973), the Court applied the test in a nontaxpayer suit. See infra notes 117-19 and accompanying text. Five years later, however, in Duke Power Co. v. Carolina Envtl. Study Group, Inc., 438 U.S. 59, 78-79 (1978), the Court explicitly repudiated the test's applieability except in taxpayer suits. See infra notes $249-58$ and accompanying text.

18. Jenkins v. McKeithen, 395 U.S. 411,423 (1969) (quoting Flast v. Cohen, 392 U.S. 83, 98 (1968)).

19. L. TRIBE, supra note $8, \S 3-27$, at 110 . 
challenged as being lawless. ${ }^{20}$ Professor Tribe's suggestion parallels that of Professor Davis, who observed:

The natural system is that of the common law: If $A$ and $B$ are private parties and A hurts B, B has standing to get a determination of the legality of A's action. Why should not the law be the same, whether $A$ is the government, and [sic] agency, an officer, or a private party, and whether the injury is to B's person, his physical property, or his intangible interests? Is not the natural system the simple one that injury in fact is enough for standing? ${ }^{21}$

Thus, Professor Davis, too, would leave only the injury-in-fact requirement for standing, noting that " $[t]$ he only problems about standing should be what interests deserve protection against injury, and what should be enough to constitute an injury." 22

This Article supports Professor Tribe's and Professor Davis' suggestion, but on a different basis. In addition to the problems outlined above, the Article suggests that the nexus requirement also overlooks one of the fundamental characteristics of American government foreshadowed in

20. Professor Tribe believes that challenges to governmental action do, and should, stand on special footing:

When official action is challenged on grounds of illegality, values beyond those tangibly protected by the violated law or constitutional provision come powerfully into play. Both the value of legality as such, and the public respect which rests on it, may be seriously impaired whenever courts equipped to remedy an illegality at the behest of a factually injured party allow clearly illegal procedures or resuits to stand on the sole ground that all of the material interests required to be considered or "accommodated" by the statutory (or even constitutional) scheme were satisfied with the official action. To say in such circumstances that the "abstract concern for vindicating the bare words of statutes seems too attenuated a justification for disturbing mutually satisfactory arrangements struck by all of the relevant public and private interests," is to deprecate the "relevant public interest" in the rule of law. In any event, letting "mutually satisfactory arrangements" stand on such a ground requires assuming or finding that those who are silent are indecd "satisfied" rather than merely ignorant, impecunious, inadequately organized, or simply exhausted. At a minimum, the requirement for nexus should be dropped and surrogate standing allowed whenever a court has reasonable ground to believe that one of these alternative explanations has played a major role in the absence of any challenge by someone with direct standing.

Id. § 3-27, at 111-12 (footnotes omitted). Thus, Professor Tribe argues that "if government's overriding duty to act lawfully is accorded serious weight," the nexus requirement ought to be abandoned as a matter of sound policy. Id. $\S 3-28$, at 113 . Justice Powell has aiso suggested abandoning the nexus test. See United States v. Richardson, 418 U.S. 166, 180 (1974) (Powell, J., concurring). His views and Richardson are discussed infra in Part II.

21. Davis, The Liberalized Law of Standing, 37 U. CHI. L. REV. 450, 468 (1970). In this respect, Professor Davis echoes Justice Frankfurter: "A litigant ordinarily has standing to challenge governmental action of a sort that, if taken by a private person, would create a right of action cognizable by the courts." Joint Anti-Fascist Refugee Comm. v. McGrath, 341 U.S. 123, 152 (1951) (Frankfurter, J., concurring). And indeed, Justice Brennan concurs in this suggestion. See infra text accompanying notes 221-25.

This Article suggests, however, that this injury-in-fact concept is underinclusive. Private parties, in their dealings with each other, are not bound by a charter by which one party creates the other and gives him or her legitimacy. Because of the nature of American government, the Davis tort metaphor fails at that point. See infra Part I.

22. Davis, supra note 21 , at 468 . 
the writings of John Locke ${ }^{23}$ and woven into the Constitution by the Framers: the concept that rights, in addition to being individually held, may also be held collectively by the body politic, which creates and provides the justification for civil government. ${ }^{24}$ In Professor Davis' terms, there are additional interests, as yet unrecognized in the law of standing, that deserve protection against injury. The existence of collective interests has been widely recognized by courts and scholars, ${ }^{25}$ but not in the context discussed here. Collective interests are most often discussed when they are perceived to be in conflict with rights or privileges asserted by an individual. ${ }^{26}$ They are not evaluated in terms of their impact on the doctrine of standing. This Article suggests that there is a class of cases where individual and collective interests, far from being opposed, actually coincide-cases where the government is charged with violating the Constitution. Moreover, in a significant subclass of those cases, current standing doctrine makes impossible both judicial protection of such collective interests and judicial insistence that government operate only within the bounds of the Constitution. The effect is that certain constitutional provisions effectively exist only at the whim and during the good will of the government, because the collective interest in enforcement of such provisions will not be protected by the courts. This Article urges, therefore, that the existence and recognition of collective rights require a modification of standing doctrine so that such rights can be protected through judicial review. ${ }^{27}$

23. See generally J. Locke, Two TREATISES OF GOVERnMENT Second Treatise (P. Laslett ed. 1960).

24. See infra notes 59-65 and accompanying text.

25. See generally infra Part III, Section $B$; see also Antieau, The Jurisprudence of Interests as a Method of Constitutional Adjudication, 27 CASE W. RES. L. REv. 823 (1977).

26. See, e.g., Morris v. Slappy, 461 U.S. 1, 14-15 (1983) (public interest in protection of victim's rights balanced against individual's sixth amendment right to counsel); Gannett $C o$. v. DePasquale, 443 U.S. 368, 383 (1979) (public interest in open trials balanced against individual's 6 th and 14th amendment rights to fair trial); Roe v. Wade, 410 U.S. 113, 153-54 (1973) (state's interest in the health of a prospective mother and in the potentiality of human life balanced against individual's constitutionally based privacy interests in making the abortion decision); Wisconsin v. Yoder, 406 U.S. 205, 213-15 (1972) (state's interest in universal compulsory education balaneed against individual's first amendment right to free exercise of religion); Camara v. Municipal Court, 387 U.S. 523, 533 (1967) (public interest in enforcement of health and fire codes balaneed against individual's fourth amendment right to privacy); Konigsberg v. State Bar, 366 U.S. 36, 49-52 (1961) (public interest in careful regulation of the fitness of attorneys balanced against individual's 1st and 14th amendment rights to free association).

27. Professor Berger has suggested that a broad concept of standing is consistent with our common law history in cases where illegal government action is challenged. His theory, however, is based on the ready availability of the prerogative writs to English citizens without requiring personal injury-in-fact and does not explicitly deal with more direct influences on the American process of creating a national government. Berger, Standing to Sue in Public Actions: Is It a Constitutional Requirement?, 78 YALE L.J. 816 (1969). Other scholars have also proposed broadening the doctrine of standing, effectively eliminating it in public actions, on the ground that it would be better policy to do so. See, e.g., Jaffe, Standing to Secure Judicial Review: Public Actions (pt. 1), 74 HARv. L. Rev. 
The Article is presented in three Parts. Part I documents the enormous effect that Locke's political philosophy had on the Constitution's Framers and traces the idea of collective rights through Locke's Second Treatise ${ }^{28}$ showing how Locke viewed government as a trustee and society as the settlor-beneficiary that forms and gives legitimacy to the government. Part II reviews the development of the current doctrine of standing and demonstrates how the current standing model creates a class of cases where government may, with impunity, violate the Constitution. Part III demonstrates the anomaly of the Supreme Court's current doctrine in a society founded on the ideas of John Locke. It then explores the constitutional provisions where collective rights have already been recognized by the courts, ${ }^{29}$ though not with respect to standing analysis. Finally, Part III proposes a revision of the current test for standing to ensure that vindication of society's collective rights is possible without creating universal standing and thus threatening the courts with a tidal wave of litigation brought by "officious intermeddlers." 30

\section{I \\ JoHN LOCKe AND THE Framers of THE CONSTItution}

It would be difficult to overstate John Locke's influence on the American Revolution and the people who created the government that followed it. ${ }^{31}$ One writer notes that most eighteenth-century liberal doctrines can be traced to Locke and his concept that community power

1265 (1961); Nichol, Rethinking Standing, 72 CALIF. L. Rev. 68 (1984). But see Sedler, Assertion of Constitutional Jus Tertii: A Substantive Approach, 70 CALIF. L. REv. 1308 (1982) (personal injuryin-fact should be required for standing, and third parties should not be able to assert others' injuries in order to get standing). By contrast, this Article proposes that it is not necessary to discard standing doctrine entirely in public actions; it merely is appropriate to recognize the full range of interests-individual and collective-deserving protection under the Constitution.

28. J. LOCKE, supra note 23.

29. I have previously identified one such right that arises from the fourth amendment, Doernberg, "The Right of the People": Reconciling Collective and Individual Interests Under the Fourth Amendment, 58 N.Y.U. L. REv. 259 (1983), but I focused on support of the collective fourth amendment right, implicit in the exclusionary rule, which is recognized by the Supreme Court itself. This Article demonstrates that the concept of collective rights has antecedents in the philosophical underpinnings of the American state.

30. See L. TRIBE, supra note $8, \S 3-22$, at 99 .

31. Locke can be regarded as the advance ideologist of the American Revolution.

He developed a set of political ideas which has very largely served as the basis for American political values and for the institutional structure which American and British government has since assumed. His importance for American political thought can hardly be overestimated; indeed, there is probably no better short summary of the ideas of Locke than the American Declaration of Independence.

D. Minar, Ideas AND Politics: The American Experience 47 (1964) (footnote omitted); see also L. LeDER, LiberTy AND AUTHORITY: EARLy AMERICAN POLITICAL IDEOlogy 1689-1763, at $37-40$ (1968). 
resides in the majority. ${ }^{32}$ To be sure, the colonists were influenced by other political philosophers as well, notably Blackstone, Hume, Montesquieu, Paine, Rousseau, Sidney, and Adam Smith, "33 "[b]ut Locke came nearest to the heart of the case. If an occasional criticism was passed on his [specific proposals], as was done by John Adams, . . . it was only to show how 'the most resplendent genius' may fail in practice."34

This is not to say, however, that the Framers accepted his theories completely and without question. In some ways, American political philosophy went beyond Locke's, as for example by its provisions for removal of officials and alteration of the form of government without political revolution. ${ }^{35}$ But as a general matter, "the framers established their government in frank Lockean style upon the consent of the governed."36 The Framers truly rejected only Locke's concept of absolute legislative supremacy over the executive and the courts, creating the "three coequal branches,"37 which furnish the primary distinction between the American and English systems of government. ${ }^{38}$ This distinction is important to the theory of standing presented in this Article. Before turning to the Supreme Court's development of the modern doctrine of standing, however, it is necessary to understand more of the phi-

32. Salvemini, The Concepts of Democracy and Liberty in the Eighteenth Century, in THE CONSTITUTION RECONSIDERED 105 (C. Read ed. 1938).

33. Maclver, European Doctrines and the Constitution, in THE CONSTITUTION RECONSIDERED, supra note 32, at 51, 52; see also Salvemini, supra note 32, at 105.

34. Maclver, supra note 33, at 52 (quoting 4 Works of JoHN ADAMS 463-64 (C. Adams ed. 1865)). The extent of the early American response to that genius is reckoned by MacIver to be nearly universal. "Add to Locke's teaching Montesquicu's more explicit doctrine of division of powers, inject into it some republican fervor, and you have the whole substance of the Virginia Bill of Rights, and indeed all the preambles, manifestoes, and declarations of principle that followed." Id. at 53; see also E. Dumbauld, The Declaration of Independence AND What It Means Today 20 (1950); A. RanNey, The Governing of MEN 152, 161-62 (1966).

Locke's influence on the American idea of separation of powers may have been as great as Montesquieu's. Daniel Minar notes that it was Locke's version of the doctrine that "later was to become so integral a part of the American political ideology and procedure." D. MiNAR, supra note 31 , at 52 .

35. E. DumbauLd, supra note 34, at 77; see also infra notes 70-100 and accompanying text.

36. Gabriel, Constitutional Democracy: A Nineteenth-Century Faith, in The Construturion ReCONSIDERED, supra note 32, at 247. Professor Mace notes, "Locke has long been considered the political theorist who exerted the greatest influence upon our natural-rights heritage. . . . Many go so far as to suggest his influence upon the American Founding Fathers was so great that the United States may be termed a Lockean nation." G. MACE, Locke, HobBES, AND THE Federalist PAPERS 9 (1979) (footnote omitted). Professor Mace disagrees with this, however, concluding that Hobbes' influence was more important. Id. at xii. The majority view, nevertheless, seems clearly to be on the side of Locke.

37. See, e.g., United States v. Nixon, 418 U.S. 683, 707 (1974); Doe v. McMillan, 412 U.S. 306, 311 n.6 (1973).

38. MacIver, supra note 33 , at 53 . 
losophy that so influenced the Framers and then to examine the specific reflections of Locke's ideas in American political thought.

\section{A. John Locke's Philosophy}

John Locke is perhaps most commonly associated with the doctrine of government by consent of the governed. Throughout the Second Treatise, ${ }^{39}$ Locke emphasized that civil government arises only when people remove themselves from the state of nature by combining to form a government. ${ }^{40}$

Men being . . . all free, equal and independent, no one can be put out of this Estate, and subjected to the Political Power of another, without his own Consent. The only way whereby any one devests himself of his Natural Liberty, and puts on the bonds of Civil Society is by agreeing with other Men to joyn and unite into a Community, for their comfortable, safe, and peaceable living one amongst another. . . . When any number of Men have so consented to make one Community or Government, they are thereby presently incorporated, and make one Body Politick, wherein the Majority have a Right to act and conclude the rest. ${ }^{41}$

39. J. LOCKE, supra note 23.

40. "To those that say, There were never any Men in the State of Nature; I will not oppose the Authority . . . . But I moreover affirm, That all Men are naturally in that State, and remain so, till by their own Consents they make themselves Members of some Politick Society . . ." Id. § 15, at 295-96; see also id. $\S 99$, at 351 , § 102, at 352-53, §§ 104-106, at 354-56, § 171, at 399-400.

41. Id. $\$ 95$, at $348-49$ (emphasis in original). Moreover, because few people entering an established civil society affirmatively consent to its government, and to avoid the illegitimacy that would result from such a mass absence of consent, Locke constructed a theory of tacit consent, struggling to ensure that the theory was neither oppressive nor illusory:

[E]very Man, that hath any Possession, or Enjoyment, of any part of the Dominions of any Government, doth thereby give his tacit Consent, and is as far forth obliged to Obedience to the Laws of that Government, during such Enjoyment, as any one under it; whether this his Possession be of Land, to him and his Heirs for ever, or a Lodging only for a Week; or whether it be barely travelling freely on the Highway; and in Effect, it reaches as far as the very being of any one within the Territories of that Government.

Id. $\$ 119$, at 365-66 (emphasis in original). Thus, Locke premised the entire existence of government on his theory of consent. Indeed, it has been noted that "[t]here is no point which Locke insisted upon more constantly and more forcefully than that all legitimate governments rest upon the consent of the governed." S. LAMPREcht, The Moral and Political Philosophy of John Locke 136 (1918). But Locke expanded the consent idea by hypothesizing a form of tacit consent embracing virtually all persons not actively engaged in forming the new state.

Students of civil procedure will recognize the genesis of two famous cases in the preceding quotation. Locke clearly foreshadows the declaration in Hanson v. Denckla, 357 U.S. 235 (1958), that, for in personam jurisdiction over the defendant to exist, "it is essential in each case that there be some act by which the defendant purposefully avails itself of the privilege of conducting activities within the forum State, thus invoking the benefits and protections of its laws." Id. at 253. And, though perhaps less emphatically, Locke's reliance on free travel upon the highway as a basis for inferring consensual submission to governmental power anticipated Hess v. Pawloski, 274 U.S. 352 (1927):

[1]n advance of the operation of a motor vehicle on its highway by a non-resident, the State may require him to appoint one of its officials as his agent on whom process may be served in proceedings growing out of such use. ... [This Court has recognized the] power of the State to exclude a non-resident until the formal appointment is made. And, having the 
One reason this part of Locke's theory is so well known is its appearance in the Declaration of Independence. ${ }^{42}$ Moreover, the concept is routinely referred to in cases where governmental action is challenged on constitutional grounds. ${ }^{43}$ But one cannot properly understand Locke's political theory solely in terms of his idea of government by consent. Indeed, even the consent theory itself cannot be understood in isolation from the rest of the Second Treatise. Consent is, of course, the hallmark of a properly governed society. "The unmistakeable sign of civil society having come into being is when every individual has resigned up to the society or the public his individual power to exercise the law of nature and protect his property." 44 But several questions remain: How should the consented-to government exercise its power? ${ }^{45}$ More important, what relationship should the government have to those who have consented to its existence, whether explicitly or tacitly? ${ }^{46}$

Government in a Lockean society is the product of a compact among people. ${ }^{47}$ Government is, in fact, the creation of such a compact,

power so to exclude, the State may declare that the use of the highway by the non-resident is the equivalent of the appointment of the registrar as agent on whom process may be served.

Id. at 356-57 (citations omitted).

42. See supra text accompanying note 3. The doctrine is also well known because it is ancient. See, e.g., Plato, Crito, in The Four Socratic Dialogues of Plato 112 (B. Jowett trans. 1903).

43. See, e.g., Nevada v. Hall, 440 U.S. 410, 426 (1979); Schlesinger v. Reservists Comm. to Stop the War, 418 U.S. 208, 233 (1974) (Douglas, J., dissenting); Perez v. Brownell, 356 U.S. 44, 64 (1958) (Warren, C.J., dissenting).

44. Laslett, Introduction to J. LocKE, supra note 23, at 106.

45. The manner in which a Lockean government is to exercise its power is beyond the scope of this Article. Locke considered this topic extensively in chapters IX through XIII of the Second Treatise. J. LockE, supra note 23, §§ I23-168, at 368-98.

46. Much has been written about Locke's concepts of individual rights and his limitations on the power of government in recognition of those rights. See, e.g., R. LEMOS, HOBBES AND LOCKE: Power AND Consent 103-08 (1978); Laslett, supra note 44, at 99-106. Professor Kendall has suggested, however, that Locke is properly viewed as an extreme majority-rule democrat, whose attention to individual rights is, at best, incidental to his main thrust. W. KENDALL, JOHN LOCKE AND The Doctrine of Majority-Rule (1959). Professor Kendall is not alone in this view. Professor Macpherson suggests that Locke's view of individualism necessarily implies a collective view of society because Locke's political civil society is supreme over the individual.

The wholesale transfer of individual rights was necessary to get sufficient collective force

for the protection of property. Loeke could afford to propose this transfer because the civil

society was to be in the control of men of property. Under these circumstances individual-

ism must, and could safely, be left to the collective supremacy of the state.

Macpherson, The Social Bearing of Locke's Political Theory, in LOCKE AND BERKELEY: A Collec. TION OF CRITICAl Essays 227 (C. Martin \& D. Armstrong eds. 1968).

Whether or not the Kendall view of Locke is entirely accurate, it begins to bring into focus the relationship of the people to government as developed in the Second Treatise. Each person in the state of nature is entitled to enforce natural law individually. See J. LockE, supra note $23, \S \S 6-8$, at $288-90, \S 13$, at 293-94. But in society the enforcement rights and power are collective.

47. See J. Gough, The Social Contract (2d ed. 1957). The idea of government as the product of a compact or contract is echoed in early American history. Jefferson accepted the contract theory as representative of an agreement among the states, id. at $236-37$, and the contract idea in fact appeared in many state constitutions through the mid-1800's, id. at 231. Justice Story saw the 
yet it is not a party to the compact. As Professor Laslett points out:

If a contract is to be set up, or understood, it is necessary that the parties to it should each get something out of it, and applied to politics this would mean that the government got something out of governing which the subjects are bound to give. Now this is what Locke was most anxious to avoid. Although contractually related to each other, the people are not contractually obliged to government, and governors benefit from governing only as fellow members of the "Politick Body." They are merely deputies for the people, trustees who can be discarded if they fail in their trust. $^{48}$

Thus, government may not properly insist upon any rights accruing to it from the people's compact. It is merely a functionary, "defined and limited by the end for which political society is established." 49

Hence, the nature of the formative process of civil government gives rise to the concept of government-as-trustee-a political trust for the public good in which the people are at once settlors and beneficiaries. ${ }^{50}$ Proper understanding of the trusteeship and the manner in which it differs from the social compact that creates civil government is essential to understanding Locke and his importance to modern American concepts of rights against the government and standing to enforce them. Locke distinguished the process of compact, which creates a community, from the further process by which the community entrusts political power to a government. In other words, Locke saw both a "contract of society" and a "contract of government," though for Locke, this second "contract" is not a contract at all-it is a trust. ${ }^{51}$

arrangement as an implicit contract between the community as a collective whole and each individual member, wherein the community agreed to protect its citizens on the condition that they obey its laws. Id. at 237. In Chisholm v. Georgia, 2 U.S. (2 Dall.) 419, 471 (1793), Chief Justice Jay describes the Constitution as "a compact made by the people of the United States." See also Munn v. Illinois, 94 U.S. 113, 124 (1876) (" 'A body politic,' as aptly defined in the preamble of the Constitution of Massachusetts, 'is a social compact by which the whole people covenants with each citizen, and each citizen with the whole people, that all shall be governed by certain laws for the common good.' "); J. LockE, supra note $23, \S 97$, at 350 , $\$ 99$, at 351 .

48. Laslett, supra note 44 , at 113 (citations omitted).

Although whoever holds legislative power is constitutionally supreme within the limits of the Constitution, they are nevertheless still only the fiduciary agents of the community. As such, they are subject to the supreme power of the community and subject to removal by the community if in its judgment they have violated their trust.

R. LEMOS, supra note 46 , at 122.

49. Laslett, supra note 44 , at 111.

50. The concept of government as trustee is not unique to Locke. "[T]he idea of trust was also very common in the seventeenth century, and while it is possible that eighteenth-century writers took it from Locke rather than from other authors, it is clear that it was already a political commonplace before Locke's time." J. Gough, JoHN LockE's Polirical PhILOSOPHY 156 (2d ed. 1973). In fact, Gough traces the trust idea, at least with respect to the executive, back to the thirteenth century and the reign of Richard II. Id. at 165; see also Laslett, supra note 44, at 112. For a general discussion of the development of trust theory in English political thought, see J. GougH, supra, at 154-92.

51. See Laslett, supra note 44 , at $112-13$. 
Several writers suggest that Locke's repeated resort to the trust metaphor ${ }^{52}$ should not be taken to connote a trust in a literal or formal sense. ${ }^{53}$ Yet it is clear in the Second Treatise that he uses the term as more than a synonym for "confidence," and that this heightened use of the trust concept is fully reflective of the political thought of his time. ${ }^{54}$ For example, John Milton, having a view of the origins of civil society similar to Locke's, argued that "the power of Kings and Magistrates is nothing else, but what is [only] derivative, transferred and committed to them in trust from the people, to the Common good of them all."5s

Locke's detailed discussion of trust demonstrates the existence of the trust and the collective nature of its creation. The legislature's supreme power

is not, nor can possibly be absolutely Arbitrary over the Lives and Fortunes of the People. For it being but the joynt power of every Member of the Society given up to that Person, or Assembly, which is Legislator, it can be no more than those persons had in a State of Nature before they enter'd into Society, and gave up to the Community. ${ }^{56}$

Locke saw a two-step progression from the state of nature to civil society: first the combination of individuals into society, and second the vesting of power in the legislature as a trust. ${ }^{57}$ Because the legislature's power is only derived from "a positive voluntary Grant and Institution" by the people, it cannot be transferred by the legislature to any other hands. ${ }^{58}$ Thus, Locke's legislature functions within the trust metaphor.

In emphasizing that the transfer of power from community to legislature is a delegation rather than an alienation, Locke explicitly makes the legislature's power subordinate to the people's "Supream Power to remove or alter the Legislative, when they find the Legislative act contrary to the trust reposed in them." 59 Consequently, the legislature is

52. J. LockE, supra note $23, \S \S 22,110-111,134,136,139,142,149,155-156,164,171,210$, 221-222, 226-227, 231, 239-240, 242.

53. See, e.g., J. Gough, supra note 47, at 175-78; Laslett, supra note 44, at 112.

54. See infra notes 56-65 and accompanying text.

55. Milton, The Tenure of Kings and Magistrates, in 40 YALE Studies IN ENGLiSH 12 (A. Cook \& W. Allison eds. 1911). Such thought was true in practice as well as in theory. During the trial of Charles I, the prosecutor explicitly presented his case to the court as a breach of trust matter, arguing that by reason of Charles' breach, he was required to answer to his superiors, the people who had established the trust. J. Gough, supra note 50, at 169 (citing J. MudDimaN, THE TRIAL OF CHARLES I (1928)). Gough also notes that the trust theory appeared, in some respects anticipating Locke's theory, in the work of Philip Hunton in 1643, id. at 171, and in R. FERGUSON, A BRIEF JUSTIFICATION OF THE PRINCE OF ORANGE's DESCENT INTO ENGLAND (1689), where the cxecutive powers of the king are described as having been delegated in trust. J. GouGH, supra note 50, at 175. Further, "the accession of James I was soon followed by far-reaching constitutional disputes between king and parliament, in which the trust concept came to bc frecly used." Id. at 176.

56. J. LockE, supra note $23, \S 135$, at $375-76$ (emphasis in original).

57. Id. $\S 136$, at $376-77$.

58. Id. $\S 141$, at $380-81$.

59. Id. $\S 149$, at $384-85$ (emphasis in original). 
responsible to the body politic in a far more direct way than to any individual member of it. ${ }^{60}$ The legislative power is explicitly "limited to the publick good of the Society," "61 and it is to the society that the legislature is responsible. ${ }^{62}$

The theory of trust so explicitly applied to the legislative power also affects the executive. For example, the limited power to call the legislature into session is one of trust, to be exercised for the benefit of the people. ${ }^{63}$ Moreover, even though the executive may be given certain prerogatives by the legislature to deal with unforeseen circumstances, the prerogatives themselves must be "imployed for the benefit of the Community, and suitably to the trust and ends of the Government."64

In all circumstances, therefore, Locke not only views the institution of government as a trust, but also as one created by the collective body of the people and responsible to it. "Locke suggests that the society as trustor assigns to the government as trustee a fund of power to be exercised on behalf of the safety (or pleasure) of the individuals of the community." 65 The obligation created by the trust is one way; the governmentas-trustee is obligated to the people, not they to it.

The collective aspect of Lockean society extends even to the point where government ceases to function properly. Perhaps the most important demonstration of the community's collective voice is found in Locke's concept of the right of revolution. The Second Treatise discusses dissolution of government at length, ${ }^{66}$ and explicitly considers the problem of a populace oppressed by its government.

But if any one should ask, Must the People then always lay themselves open to the Cruelty and Rage of Tyranny? . . . I Answer: Self-defence is a part of the Law of Nature; nor can it be denied the Community, even against the King himself. . . . This therefore is the Priviledge of the People in general, above what any private Person hath; That particular Men are allowed . . . to have no other Remedy but Patience; but the Body of the People may with Respect resist intolerable Tyranny. . . . ${ }^{67}$ The collective right of revolution may be exercised whenever "tyranny"

60. In this respect, of course, the structure of Locke's political system supports the views of Kendall and Macpherson that Locke is a collective, majoritarian democrat. See supra note 46.

Locke's view of the legislature's responsibility to the collective body politic finds its ultimate expression in his right of revolution, discussed infra at notes $66-100$ and accompanying text.

61. J. LOCKE, supra note $23, \S 135$, at $375-76$ (emphasis in original); see also id. $\$ 171$, at 399 $400, \S 216$, at $427, \S 229$, at 435 .

62. Locke's view of the continuing responsibility of the legislature to the people contrasts sharply with Hobbes' insistence on the absolute rights of the sovereign once created by the social compact. See T. HobBes, LEviathan 113-20 (M. Oakeshott ed. 1960).

63. J. LockE, supra note $23, \S 156$, at $389-90$.

64. Id. $\S 161$, at 393 .

65. D. MinaR, supra note 31 , at 49.

66. J. LOCKE, supra note $23, \S \S 211-243$.

67. Id. § 233, at 438-39, (quoting (in translation) W. BARCLAy, DE REGNO ET REgali Pote- 
occurs, that is when government acts beyond purposes specified by the people. ${ }^{68}$ Thus, the collective rights that underlie the formation of civil government also give rise to the collective right to dissolve the government when the people's trust is breached. ${ }^{69}$

This treatment of the right of revolution illustrates the pervasive effect that the method used to form a civil society has upon the society's relationship with the government it creates. It also exemplifies a corollary to the theory of trust: government is accountable to the people as a whole. The right of revolution Locke describes is no more than a method by which the accounting may be made; the accountability must be to the group, not to any individual member of it. ${ }^{70}$

\section{B. The Influence of John Locke on American Political Thought}

Locke's direct influence on the formation of the new American government is evident in many places. The first statement of American governmental principles is the Declaration of Independence, and here Locke's impact is unmistakable. ${ }^{71}$

Implicit in the Declaration is the "social compact" theory, that a people is a political organization of persons, who, having theretofore lived in a "state of nature" without being united by any political bonds, associate

stati adversus Buchananum, Brutum, Boucherium et Reliquos Monarchomachos (1600)); see also S. LAMPRECHT, supra note 41, at 143.

68. J. LOCKE, supra note $23, \S 199$, at 416.

69. The right of revolution, however, was limited by Locke to cases where government had actually breached its trust.

Locke. . . insisted that government was merely the bearer of executive power on trust for the community. But in Locke's case remnants of the belief in a contract between the community and the government had restricted the right of revolution against the government to occasions when government had betrayed its trust or failed in its proper task.

F. HiNSLEY, SovEREIGNTY 153-54 (1966). Moreover, the right of revolution was not exercisable in response to isolated acts of tyranny; resistance was authorized only when there was a calculated governmental design to subvert the law. J. FRANKLIN, JoHN LOcke AND THE THEORY OF SoverEIGNTY 95 (1978). On the other hand, government's failure to comply with the conditions for its existence created not merely a right, but a duty to overthrow the government. See R. AARON, JoHN LOCKE 286 (1937); R. LEMOS, supra note 46, at 121-22; A. RANNEY, supra note 34, at 151.

70. See S. LAMPRECHT, supra note 41 , at 146 , where the author notes that under Locke's theory, the majority of the people create the social compact, so only the majority may dissolve it. No minority is ever warranted in disturbing the peace of the community by resisting government. Thus, the right of revolution is designed, in Locke's view, to deal with the situation where government fails to rule within its proper boundaries. Professor Kendall compares the relationship to that of agent and principal.

The relation between the government of the day in Locke's system and the society from which it derives its powers is, quite simply, assimilable to that between principal and agent in Anglo-American law; and for the government to claim vis-a-vis the society for which it acts powers which the society has not entrusted to it would, on Locke's showing, be as preposterous as for an agent to claim, vis-di-vis his principal, a freedom to do in the latter's name things which the latter does not wish [to be] done.

W. KENDALL, supra note 46, at 96 (emphasis in original).

71. See E. Dumbauld, supra note 34, at 42; see also A. Kelly \& W. HArbison, The Amer1CAN CONSTITUTION: ITS ORIGINS AND DEvelopMENT 90 (1948). 
themselves together and bind themselves by compact for the purpose of establishing government. It is the voluntary union of individuals that creates the "people" or state for secular political purposes, just as under the Puritan covenant theory it creates the church for religious purposes. $^{72}$

The parallel to Locke's political theory is patent. One finds Locke's ideas, however, even more directly evidenced in the Declaration. "We hold these truths to be self-evident, that all men are created equal"73 compares with Locke's "Men being, as has been said, by Nature, all free, equal and independent."74 The Declaration's assertion of the people's right to "Life, Liberty, and the pursuit of Happiness"75 is traceable to Locke's "Life, Liberty and Estate."76 "[T]o secure these rights,"77 referring to the trilogy of "unalienable" rights, reflects Locke's view of the state of nature as understood by Jefferson. Such rights are not "created" but rather are "secured" because they antedate government; they are rights people enjoy even in the state of nature. ${ }^{78}$ Finally, the well-known phrase "deriving their just powers from the consent of the governed"79 corresponds directly to Locke's assertion that "Men are naturally free, and the Examples of History shewing, that the Governments of the World, that were begun in Peace, had their beginning laid on that foundation, and were made by the Consent of the People." 80 Indeed, Richard Henry Lee of Virginia complained that Jefferson had copied the Declaration from Locke. ${ }^{81}$ Locke's influence on Jefferson is certainly not surprising, since Jefferson spoke of Locke as one of the three greatest men of all time ${ }^{82}$ and regarded Locke's work as one of the " 'elementary books of public right." "83

Locke's influence did not stop with Jefferson or his Declaration of

72. E. DumbauLD, supra note 34 , at 31-32 (footnote omitted).

73. The Declaration of Independence para. 2 (U.S. 1776).

74. J. LOCKE, supra note $23, \S 95$, at 348 .

75. The Declaration of Independence para. 2 (U.S. 1776).

76. J. LocKE, supra note $23, \S 87$, at 341 . Moreover, the phrase "pursuit of happiness" is said to appear in Locke's philosophical writings. E. DUMBAuLD, supra note 34, at 60.

77. The Declaration of Independence para. 2 (U.S. 1776).

78. E. DumbauLD, supra note 34 , at 63 ; see also J. LoCKE, supra note $23, \S 6$, at 289.

79. The Declaration of Independence para. 2 (U.S. 1776).

80. J. LocKE, supra note $23, \S 104$, at 354 (emphasis in original); see also id. $\S 119$, at 365-66.

81. E. DUMBaULD, supra note 34 , at 56 . "The Declaration of Independence was almost pure Locke." Elliott, The Constitution as the American Social Myth, in THE Constitution ReConsidERED, supra note 32, at 216. One author is kinder to Jefferson than was Mr. Lee: "[W] would hardly know of [Jefferson's] familiarity with John Locke's Two Treatises of Government if he had not incorporated passages almost word for word in the Declaration of Independence, apparently unaware that he was doing so." E. Morgan, American Slavery, American Freedom: The ORDEAL OF COLONIAL VIRGINIA 375 (1975).

82. MacIver, supra note 33, at 52. The other two were Newton and Bacon. Id.

83. C. WILTSE, THE JefFERSONIAN TRADITION IN AMERICAN DEMOCRACY 46 (1935) (quoting WRITINGS, XVI, 118-19 (May 8, 1825) (Thomas Jefferson to Henry Lee)). 
Independence. Historian Clinton Rossiter notes that Samuel Adams can properly be regarded as an intellectual descendant of Locke, ${ }^{84}$ and Locke's concept of the state of nature is implicit in Benjamin Franklin's views of the American Indians. ${ }^{85}$ Moreover, "[i]n his natural-rights assumptions, his moderation, and his reasonableness, Locke was an intellectual godparent of James Madison, the Father of the Constitution." ${ }^{186}$ Indeed, the builders of the American government routinely referred to Locke's writings with respect and reverence. ${ }^{87}$

Locke's fiavor is found as well in documents other than the Declaration of Independence. His ideas were adopted by a 1774 resolution of the North Carolina Assembly asserting that governmental invasion of liberties was justification for revolution. ${ }^{88}$ Locke's philosophy on revolution may well have contributed to the first amendment's provision of the right to petition for redress of grievances. ${ }^{89}$ And while Locke's famous trilogy of life, liberty and estate ${ }^{90}$ became transmuted to the more popularly known life, liberty and the pursuit of happiness in 1776,91 it reappeared substantially in its original form in the fifth and fourteentl amendments. ${ }^{92}$ Nor was Locke's influence limited to these three amendments. "The blended traditions of Coke and Locke were conveyed into the incipient stream of American constitutional law by the bills of rights of the early State constitutions and by judicial review, which soon after 1800 became a feature of all of them."93 For example, Professor Elliott traces American constitutional structure directly to Locke, either as an intentional imitation or as a partial reaction to Locke's emphasis on majority rule. $^{94}$ Elliott notes that Locke drew directly from the Magna Carta,

84. C. Rossiter, 1787: THE GRAND CONVENTION 68 (1966). But Adams went beyond Locke-he rejected the possibility of tacit consent to government by the governed, insisting instead that consent be explicit. MacIver, supra note 33, at 54.

85. MacIver, supra note 33 , at 52.

86. L. MCDONald, Western Political Theory, Part 2: From Machiavelli to BURKE 326 (1968). Locke's theory of government was reflected in other colonial thought as well, notably the works of James Otis and John Dickenson. See D. MINAR, supra note 31, at 72-76.

87. C. BeCKER, THE DECLARATION OF INDEPENDENCE 75-76 (1942). One even finds reference to the works of Locke as the subjects of specific testamentary bequests, as was done, for example, by Josiah Quincy in 1774. Id.

88. E. Dumbauld, supra note 34, at 104.

89. See U.S. Const. amend. I; E. DumBauld, supra note 34, at 104-05.

90. J. LoCKE, supra note $23, \S 87$, at 341 .

91. A. KelLY \& W. HARBISON, supra note 71, at 90; see also Elliott, supra note 81, at 216.

92. U.S. CoNST. amends. V, XIV. Actually, Locke's original form was reflected earlier in American thought. "The first resolution of the Declaration [of Rights published by Congress in 1774 was] an echo of John Locke [in providing that] all men are entitled to life, liberty, and property, and that they cannot be deprived of these rights without their consent." R. RUTLAND, THE BIRTH OF THE BILL OF RIGHTS 1776-1791, at 27 (1955).

93. E. CoRWIN, Liberty Against Government 172 (1948). Professor Minar sees Locke's natural rights philosophy carried through the Declaration of Independence into its "most effective operational form in the American Bill of Rights." D. MINAR, supra note 31, at 51.

94. See Elliott, supra note 81, at 217-18; $c f$. W. KeNDALL, supra note 46. 
which the colonists used to justify the American revolution. Moreover, he traces the text of sections nine and ten of article I and all of the Bill of Rights directly to Locke's influence. Thus, the Constitution, as well as the Declaration of Independence, is traceable to Locke's natural rights philosophy-the concept that some rights cannot be alienated by individuals in forming a government. The Bill of Rights "built upon the ideas of that English philosopher whose pioneermg work first grappled with the fundamentals of society in terms of the balancing of freedom and rights-John Locke."95

Wholly apart from Locke's traceable influence on particular documents, American society adopted Locke's view of the relationships between governed and government and among the governed themselves. Locke's contract analogy was used by eighteenth-century citizens to explain these relationships, 96 and the system of American government reflects Locke's concept of government as the product of a contract among people rather than between rulers and ruled. ${ }^{97}$ Americans espoused a natural rights philosophy, which became the foundation of the American political system. "They endorsed the Lockean theory of a state of nature, inalienable natural rights, a social compact, a society rooted in popular sovereignty, the consent of the governed, and the right of revolution under conditions of intolerable oppression." 98

The American political system has, however, modified Locke's model by developing two methods of governmental accountability other than revolution: the elective process and judicial review. ${ }^{99}$ The electoral process allows the people to replace those exercising government's power when the people believe government action is unwise. The judicial process is explicitly reserved to correct governmental actions perceived to be unlawful. ${ }^{100}$ Thus, when government violates the basic statements of

95. Shotwell, Freedom-Its History and Meaning, in FreEdom: ITS MEANING 12-13 (R. Anshen ed. 1940).

96. G. Wood, The Creation of the American Republic 1776-1787, at 289 (1969).

97. Id. at 601; see also supra notes $46-49$ and accompanying text.

98. N. Riemer, The Democratic Experiment 101 (1967).

99. Locke himself emphasized that resort to extra-legal force was not justified so long as recourse to law reinained. See P. MAIER, From Resistance to Revolution: Colonial RadiCALS AND THE DEVElopment of AMERICAN OPPOSITION to BRITAIN, 1765-1776, at 32 (1972).

100. In fact, the courts explicitly refuse to consider whether governmental acts are wise or unwise. See, e.g., South Carolina State Highway Dep't v. Barnwell Bros., 303 U.S. 177, 189-92 (1938); Village of Euclid v. Ambler Realty Co., 272 U.S. 365, 395 (1926); Jacobson v. Massachusetts, 197 U.S. 11, 30-31 (1905).

The Constitution "incorporated an instrument which was to reduce the supreme legislature of Locke's thinking (and Jefferson's) to the 'creature of the Constitution.' That instrument was, of course, the Supreme Court . . . through which the doctrine of judicial review developed." Elhott, supra note 81 , at 218 . The remaining question, however, concerns who shall speak for the collective society in the courts when government acts outside of its powers but not so far as to make revolution appropriate. That question will be considered infra im Parts II and III. 
constitutional principle, the structure of the modified Lockean society suggests resort to the courts. In cases where government abuses cannot be corrected by resort to the polls, the right to government accountability can only be safeguarded by the courts. The next part of this Article, therefore, considers the Supreme Court's approach to the right of people to challenge unconstitutional government action, a concept dealt with in large part under the rubric of standing.

II

\section{The Current Doctrine of Standing In Public Actions}

In recent standing cases, ${ }^{101}$ the Supreme Court has struggled to develop standards to determine which issues are appropriate for judicial resolution. Determining whether a particular matter is fit for judicial resolution embraces more than the doctrine of standing to be discussed here; it truly concerns the broader concept of justiciability. In Flast $v$. Cohen, ${ }^{102}$ the Court noted:

[T] je judicial power of federal courts is constitutionally restricted to "cases" and "controversies." . . . Embodied in the words "cases" and "controversies" are two complementary but somewhat different limitations. In part those words limit the business of federal courts to ques. tions presented in an adversary context and in a form historically viewed as capable of resolution through the judicial process. And in part those words define the role assigned to the judiciary in a tripartite allocation of power to assure that the federal courts will not intrude into areas committed to the other branches of government. Justiciability is the term of art employed to give expression to this dual limitation placed upon federal courts by the case-and-controversy doctrine. ${ }^{103}$

Standing, like the judicial doctrines concerning political questions, advisory opinions, and mootness, was created to limit judicial power to cases in which adversarial presentation is possible and legislative or executive prerogatives are not infringed. ${ }^{104}$ The exact contours of these doctrines limiting justiciability, however, are by no means clear; ${ }^{105}$ they involve "a blend of constitutional requirements and policy considerations." 106

Standing concerns whether the party seeking to invoke the judicial

101. For purposes of this Article, "recent" refers to cases beginning with Flast v. Cohen, 392 U.S. 83 (1968), after which, this Article suggests, the problems with traditional standing began to appear forcefully.

102. 392 U.S. 83 (1968).

103. Id. at $94-95$.

104. Id. at 95.

105. Id.

106. Id. at 97; see also supra notes 11-18 and accompanying text. 
power is the appropriate party to do so. "The fundamental aspect of standing is that it focuses on the party seeking to get his complaint before a federal court and not on the issues he wishes to have adjudicated." 107 Doctrines other than standing focus on the issues. Thus, though a plaintiff may liave standing, the courts may decline to adjudicate his case because it raises a political question or is moot. ${ }^{108}$ Conversely, the courts may refuse to adjudicate otherwise justiciable matters on the ground that the plaintiff lacks standing. ${ }^{109}$ This Part will focus on the latter category of cases. Many of the cases falling into this category present the troubling prospect of issues that are, or should be, justiciable but for which no potential plaintiff exists. This Part will also compare these cases with contemporaneous cases in which plaintiffs were found to liave standing to determine whether there are principled differences between the two groups.

\section{A. Denials of Standing}

\section{The Early 1970's}

In Sierra Club v. Morton, ${ }^{110}$ the Supreme Court considered an environmental protection suit brought by the Sierra Club against the Secretary of the Interior challenging the proposed development and use of certain federal lands. While the Court found that aestlietic injury was sufficient injury-in-fact to confer standing, ${ }^{111}$ it nonetheless dismissed the action for lack of standing because the Sierra Club, apparently for tactical reasons, chose not to allege harm to specific club members or individuals." 12 The Court required the party seeking standing to allege "more

107. Flast, 392 U.S. at 99; see also Sierra Club v. Morton, 405 U.S. 727, 731-32 (1972).

108. See, e.g., DeFunis v. Odegaard, 416 U.S. 312 (1974) (declaring the controversy moot despite plaintiff's standing); Colegrove v. Green, 328 U.S. 549 (1946) (pohitical question); Pacific States Tel. \& Tel. Co. v. Oregon, 223 U.S. 118 (1912) (pohtical question).

109. See, e.g., Sierra Club v. Morton, 405 U.S. 727 (1972), discussed infra in notes 110-16 and accompanying text.

110. 405 U.S. 727 (1972).

111. Id. at 734. The Court treated the case as one of first inpression, noting that its prior cases did not address "the question, which has arisen with increasing frequency im federal courts in recent years, as to what must be alleged by persons who claim injury of a noneconomic nature to interests that are widely shared." Id.

112. Thus, it is possible to read Sierra Club narrowly as a case involving a defect in pleading rather than announcing any new ideas about standing. While as a technical matter this may be correct, such a reading ignores what was truly going on in Sierra Club. Certainly a broad reading of the complaint, as encouraged by FED. R. Crv. P. 8(f), see, e.g., Conley v. Gibson, 355 U.S. 41 (1957); United States v. White County Bridge Coının'n, 275 F.2d 529 (7th Cir.), cert. denied, 364 U.S. 818 (1960), would have permitted the inference that the required individualized injury existed, particulariy in light of one paragraph of the complaint, which the Court felt compelled to quote before disregarding.

"Plaintiff Sierra Club is a non-profit corporation . . . [with] approximately 78,000 [melnbers] nationally .... . For many years the Sierra Club by its activities and conduct has exhibited a special interest in the conservation and the sound maintenance of the national 
than an injury to a cognizable interest . . . . [T] he party seeking review [must] be himself among the injured." 113 Although the Court recognized the public interest aspect of the Sierra Club's complaint, ${ }^{114}$ it was unwilling to recognize such a "public action" unless the public's representative-the plaintiff-alleged personal harm. ${ }^{15}$ In so holding, the Court made it clear that the concept of a plaintiff acting as the public's representative might still be viable, but not in the absence of some allegation of individual injury to the would-be representative. ${ }^{116}$

In 1973, the Court turned its attention from injury-in-fact and expanded the scope of the nexus test in Linda R.S. v. Richard D. ${ }^{117}$ There, the mother of an illegitimate child challenged Texas' practice of refusing to enforce its penal statute addressing nonsupport of children against parents of illegitimate children. The plaintiff asserted that the state's practice denied her child equal protection. The Court affirmed the district court's dismissal of the case on standing grounds. Justice Marshall, writing for the majority, readily conceded that the plaintiff had satisfied the injury-in-fact requirement, but held that she had failed to satisfy the

parks, game refuges and forests of the country, regularly serving as a responsible representative of persons similarly interested. One of the principal purposes of Sierra Club is to protect and conserve the national resources of the Sierra Ncvada Mountains. Its interests would be vitally affected by the acts hereinafter described and would be aggrieved by those acts of the defendants as hereinafter more fully appears."

Sierra Club, 405 U.S. at 735 n.8 (quoting complaint at I 3). At the same time, the Court specifically noted the possibility of the Sierra Club amending its complaint after remand to the district court. Id. at 736 n.8. Professor Nichol observes that the same sort of inversion of the normal pleading rules can be seen in Simon v. Eastern Ky. Welfare Rights Org., 426 U.S. 26 (1976), and Warth v. Seldin, 422 U.S. 490 (1975). Nichol, supra note 27, at 72 n.25. Simon and Warth are discussed infra in notes $159-78$ and accompanying text.

Justicc White is reported to have been especially exasperated with plaintiffs' failure or refusal to prepare themselves to meet the standing question. "'Why didn't the Sierra Club have one goddamn member walk through the park and then there would have been standing to sue,' White remarked, before joiming the four-member majority." B. WOODWARD \& S. ARMSTRONG, THE BRETHREN 164 n.* (1979).

113. Sierra Club, 405 U.S. at 734-35.

114. Id. at 736-37.

115. The Court also noted, id. at $736 \mathrm{n} .9$, with apparent disapproval that the Second Circuit had recognized representative standing of the type asserted by the Sierra Club in Citizens Comm. for the Hudson Valley v. Volpe, 425 F.2d 97, 105 (2d Cir.), cert. denied, 400 U.S. 949 (1970).

116. The Court's reliance upon the injury-in-fact test reflected earlier standing decisions, notably Baker v. Carr, 369 U.S. 186 (1962), and Flast v. Cohen, 392 U.S. 83 (1968). Flast, in fact, sets out what is now taken as the basic framework of standing inquiry by delineating the two-part test for standing. See supra notes 10-17 and accompanying text. The Court insisted on an allegation of individual injury even though it favorably noted the emerging trend toward recognition of noneconomic injuries as appropriate predicates for standing.

[T]he interest alleged to have been injured "may refiect 'aesthetic, conservational, and recreational' as well as economic values." But broadening the categories of injury that may be alleged in support of standing is a different matter from abandoning the requirement that the party secking review must himself have suffered an injury.

Sierra Club, 405 U.S. at 738 (quoting Association of Data Processing Serv. Orgs. v. Camp, 397 U.S. 150,154 (1970)).

117. 410 U.S. 614 (1973). 
nexus test. ${ }^{118}$ Specifically, the Court found that the plaintiff had not demonstrated either that the absence of support payments resulted from nonenforcement of the penal law section, or that enforcement, if ordered, would cause support payments to begin. ${ }^{119}$ Thus, the majority was not satisfied that the plaintiff's injury resulted from violation of the constitutional right on which she based her complaint.

The Court next denied standing in United States $v$. Richardson ${ }^{120}$ and Schlesinger v. Reservists Committee to Stop the War. ${ }^{121}$ In Richardson, a taxpayer sought to have the Central Intelligence Agency Act $^{122}$ declared unconstitutional because it allegedly permitted a type of accounting for funds inconsistent with the requirements of the accountability clause. ${ }^{123}$ The Court, in a five-to-four decision, ruled that Richardson had no standing. ${ }^{124}$ Although the plaintiff sued as a taxpayer, he failed the nexus test ${ }^{125}$ because his attack on the CIA's practice was not based on the taxing and spending power. ${ }^{126}$ The Court, therefore, found that Richardson was "seeking 'to employ a federal court as a forum in which to air his generalized grievances about the conduct of government." "'127

The majority did not rest on the nexus ground alone; it went on to

118. Flast, 392 U.S. 83 (1968); see supra notes 9-17 and accompanying text.

119. Linda R.S., 410 U.S. at 618 . Justice White took issue with the majority's lack of faith in the salutary effect of threatened penal sanctions.

I had always thought our civilization has assumed that the threat of penal sanctions had something more than a "speculative" effect on a person's conduct . . . . Certainly Texas does not share the Court's surprisingly novel view. It assumes that criminal sanctions are useful in coercing fathers to fulfill their support obligations to their legitimate children.

Id. at 621 (White, J., dissenting).

120. 418 U.S. 166 (1974).

121. 418 U.S. 208 (1974).

122. 50 U.S.C. $\$ \S 403 a-403 j$ (1976 \& Supp. V 1981).

123. U.S. CoNST. art. I, $\S 9$, cl. 7: "No Money shall be drawn from the Treasury, but in Consequence of Appropriations made by Law; and a regular Statement and Account of the Receipts and Expenditures of all public Money shall be published from time to time."

Before suing, Richardson had sought copies of the CIA's financial statements from the Government Printing Office, which referred his request to the Fiscal Service of the Bureau of Accounts of the Department of the Treasury. That office provided him some general records of expenditures, but reported that it had no information specifically relating to CIA expenditures. Richardson thereupon asked the Treasury Department to seek the Attorney General's opinion of the constitutionality of the CIA Act, and only upon the Department's refusal to do so was the action commenced. Richardson, 418 U.S. at 168.

124. The district court had dismissed the case for lack of standing, but the Third Circuit, sitting en banc, reversed with three judges dissenting. Of the majority in that court, three judges found that Richardson had taxpayer standing under Flast v. Cohen, 392 U.S. 83 (1968); and one judge found that he had citizen standing. Richardson v. United States, 465 F.2d 844 (3d Cir. 1972) (en banc), rev'd, 418 U.S. 166 (1974).

125. See supra notes 9-17 and accompanying text.

126. Richardson, 418 U.S. at 175; see U.S. ConST. art. I, \& 8, cl. I.

127. Richardson, 418 U.S. at 175 (quoting Flast v. Cohen, 392 U.S. 83, 106 (1968)). 
explain that Richardson could not demonstrate injury-in-fact from the challenged practice.

"It is an established principle that to entitle a private individual to invoke the judicial power to determine the validity of executive or legislative action he must show that he has sustained or is immediately in danger of sustaining a direct injury as the result of that action and it is not sufficient that he has merely a general interest common to all members of the public." 128

The Court declined to recognize Richardson's interest as differentiable from that of any other member of the public. If there was any injury, the Court refused to find that Richardson was harmed more than anyone else. ${ }^{129}$ Thus, the majority found that Richardson failed to satisfy any part of the test for standing. In this respect, Richardson echoed the insistence of Sierra Club that the plaintiff must plead and be prepared to prove injury to himself as an individual, obviously an impossibility in the sort of case Richardson brought. At the same time, the Court purported not to leave Richardson remediless. "In a very real sense," the Court held, "the absence of any particular individual or class to litigate these claims gives support to the argument that the subject matter is committed to the surveillance of Congress, and ultimately to the political process." 130 The plaintiff, therefore, was admonished to take his case to the ballot box, ${ }^{131}$ an idea repeated in Schlesinger v. Reservists Committee to Stop the War. ${ }^{132}$

In Schlesinger, several members and former members of military reserve units who were opposed to the war in Viet Nam challenged the constitutionality of members of Congress holding commissions in the military reserves. ${ }^{133}$ In an analysis similar to that in Richardson, a six-to-

128. Id. at 177-78 (quoting Ex parte Levitt, 302 U.S. 633, 634 (1937) (per curiam) (emphasis supplied by the Richardson Court)).

129. The Court relied explicitly on Ex parte Levitt, 302 U.S. 633 (1937). Levitt, a member of the Supreme Court Bar, challenged Justice Black's clevation to the bench on the ground that Justices' retirement benefits had been increased while Justice Black served as Senator from Alabama, and that his appointment thereforc violated the ineligibility clause. U.S. CoNST. art. I, $\S 6, \mathrm{cl} .2$; "No Senator or Representative shall, during the Time for which he was eleeted, be appointed to any civil Office under the Authority of the United States, . . . the Emoluments whereof shall have been encreased during such time . . . . The Court, per curiam, found Levitt without standing and declined to consider the matter further.

130. Richardson, 418 U.S. at 179.

131. There are several problems with the Court's suggested political substitute for judicial intervention. See infro notes 307-27 and accompanying text.

132. 418 U.S. 208, 227 (1974): "Our system of government leaves many crucial decisions to the political processes."

133. Specifically, the plaintiffs sought a declaration that a Congressman's membership in the reserves violated the incompatibility clause, U.S. CoNST. art. I, § 6, cl. 2 ("[N]o Person holding any Office under the United States, shall be a Member of either House during his Continuance in Office"). In addition, the plaintiffs sought an injunction barring the Secretary of Defense from enrolling any member of Congress in the reserves and directing the Secretary to strike from the reserve rolls 
three Court ${ }^{134}$ found that the plaintiffs lacked standing. The majority affirmed the district court's finding that plaintiffs lacked standing as taxpayers, ${ }^{135}$ but overturned its conclusion that they had standing as citizens. ${ }^{136}$

The Court focused upon the plaintiffs' inability to demonstrate any injury-in-fact or any individual interest differentiable from that of the citizenry generally. ${ }^{137}$ The majority noted that recent cases had broadened standing by expanding the concept of judicially cognizable injury, ${ }^{138}$ but declined to regard that trend as an abandonment of the injury-in-fact test. ${ }^{139}$ " "Abstract injury is not enough." "140 The Court concluded by discussing the policy reasons for refusing to recognize citizen standing:

All citizens, of course, share equally an interest in the independence of each branch of Government. In some fashion, every provision of the Constitution was meant to serve the interests of all. Such a generalized interest, however, is too abstract to constitute a "case or controversy" appropriate for judicial resolution. The proposition that all constitutional provisions are enforceable by any citizen simply because citizens are the ultimate beneficiaries of those provisions has no boundaries. ${ }^{141}$

Therefore, as in Richardson, the Court found the political process was

any member of Congress then enrolled, to discharge any Reservist subsequently elected to Congress, and to recover any pay given to members of Congress as Reservists. Schlesinger, 418 U.S. at 211.

134. Justice Stewart moved from the dissent in Richardson into the majority in Schlesinger, explaining in the latter that the plaintiffs had failed to allege that the defendants had refused to perform an affirmative duty under the Constitution and that, in such circumstances, none of the petitioners could demonstrate injury-in-fact. Schlesinger, 418 U.S. at 228-29 (Stewart, J., concurring).

135. Id. at 215-16. The plaintiffs had asserted four bases for standing in the district court: as persons opposed to the United States' involvement in Viet Nam; as officers and enlisted personnel of the reserves who were not members of Congress; as taxpayers; and as citizens. The district court upheld standing only on the citizen theory. See Reservists Comm. to Stop the War v. Laird, 323 F. Supp. 833 (D.D.C. 1971), aff'd mem., 495 F.2d 1075 (D.C. Cir. 1972), rev'd sub nom. Schlesinger v. Reservists Comm. to Stop the War, 418 U.S. 208 (1974).

136. Schlesinger, 418 U.S. at 224.

137. Id. at 217. The Court noted that this sort of generalized grievance had been rejected as a basis for taxpayer standing. Id. (citing Flast v. Cohen, 392 U.S. 83 (1968)). The Court has never explained why the fact that all citizens might wish to challenge governmental conduct inconsistent with the Constitution logically suggests a finding of no standing.

138. Id. at 218 (citing Association of Data Processing Serv. Orgs., Inc. v. Camp, 397 U.S. 150, $154(1970))$.

139. Id. at 218-19 (citing Sierra Club v. Morton, 405 U.S. 727, 738 (1972)).

140. Id. at 219 (quoting O'Shea v. Littleton, 414 U.S. 488, 494 (1974)). The Court also regarded Ex parte Levitt, 302 U.S. 633 (1937), as long-standing authority for this proposition. See supra note 129.

141. Schlesinger, 418 U.S. at 226-27 (footnote omitted). This Article suggests that citizen standing is appropriate in cases like Schlesinger and proposes a theory of standing that does have boundaries. See infra Part III, Section $C$. 
the appropriate remedy. ${ }^{142}$

The Richardson dissenters were quick to note the implications of the Court's ruling. Justice Stewart, joined by Justice Marshall, argued that Richardson was a typical Hohfeldian plaintiff, seeking to exercise his right to receive information and to compel the government to fulfill its corresponding duty to supply it. ${ }^{143}$ Indeed, Justice Stewart pointed out that if the government had owed Richardson money rather than information, no one would have questioned his standing. "I see no reason for a different result when the defendant is a Government official and the asserted duty relates not to the payment of money, but to the disclosure of items of information." 144 Justice Stewart, therefore, would have found that whenever government owes an affirmative duty under the Constitution, injury-in-fact is established by the nonperformance of that duty.

Justice Douglas, dissenting in Schlesinger, would also have found standing based on both citizenship and taxpayer status. ${ }^{145}$ Referring to the injury-in-fact requirement, he noted:

We have insisted that more than generalized grievances of a citizen be shown, that he must have a "personal stake in the outcome." . . . But that "personal stake" need not be a monetary one. In Baker v. Carr it was the right to vote, an important badge of citizenship. The "personal stake" in the present case is keeping the Incompatibility Clause an operative force in the Government by freeing the entanglement of the federal bureaucracy with the Legislative Branch. ${ }^{146}$

Justice Douglas, therefore, would have held each citizen's interest in the proper operation of government-an interest that the Schlesinger majority regarded as too abstract to be judicially cognizable-sufficient to support standing. ${ }^{147}$

Justice Marshall also would have found citizen standing in Schlesinger. Marshall noted that the incompatibility clause was intended

142. See supra notes $130-32$ and accompanying text. But see infra notes $307-27$ and accompanying text.

143. United States v. Richardson, 418 U.S. 166, 203 n.2 (1974) (Stewart, J., dissenting) (citing Hohfeld, Some Fundamental Legal Conceptions as Applied in Judicial Reasoning, 23 YALE L.J. 15 (1913) and Jaffe, The Citizen as Litigant in Public Actions: The Holffeldian or Ideological Plaintiff, 116 U. PA. L. REv. 1033 (1968)). For Hohfeld, a plaintiff could bring suit only if he was vindicating a right for which there was a correlative duty owed him by the defendant.

144. Id. at 203 (Stewart, J., dissenting).

145. Schlesinger v. Reservists Comm. to Stop the War, 418 U.S. 208, 232 (1974) (Douglas, J., dissenting).

146. Id. at 234 (Douglas, J., dissenting) (quoting Baker v. Carr, 369 U.S. 186, 204 (1962)).

147. Justice Douglas distinguished Ex parte Levitt, 302 U.S. 633 (1937), the case challenging Justice Black's appointment to the bench, see supra note 129, ou the ground that standing had been denied there because the injury claimed under the incompatibility clause was too speculative, since it involved retirement benefits that might never accrue rather than salary. He noted that Justice Black never received any retirement benefits. Schlesinger, 418 U.S. at 234-35 (Douglas, J., dissenting). Whether this distinction is persuasive is left to the reader. 
to avoid conflicts of interest. ${ }^{148}$ In his view, the plaintiffs' complaint did not necessarily reflect the interests of all citizens in having government abide by the Constitution. Rather, the complaint concerned the plaintiffs' first amendment right to petition the government for redress of grievances and to have a government free of conflicts of interest when it considered such petitions. ${ }^{149}$ Thus, Marshall found injury-in-fact to be a specific constitutional right and distinguished this injury from the abstract complaint that the majority found to be insufficient to sustain standing.

Justice Brennan, in a dissent addressed to both Schlesinger and Richardson, ${ }^{150}$ would have found standing in each. As to Richardson, Justice Brennan argued that injury-in-fact was established because Richardson had a personal right to receive the budget information concerning the CIA. ${ }^{151}$ And in Schlesinger, he would have found injury-infact by reason of plaintiffs' taxpayer status. ${ }^{152}$

Addressing the nexus requirement, Justice Brennan argued that it was not properly a part of standing analysis:

The Court's further inquiry, in each of these cases, into the connection between "the zone of interests to be protected or regulated by the statute or constitutional guarantee in question," . . . and the "interest sought to be protected by the complainant," . . . is relevant, not to "standing" but, if at all, only to such limitations on exercise of the judicial function as justiciability ... or reviewability. . . 153

Justice Brennan thus viewed injury-in-fact as the only test for standing.

Thus, although a substantial minority of the Court had articulated preferences for a broader concept of standing in public actions, by the mid-1970's the Court had developed two distinct approaches using standing to restrict access to the courts. The first, exemplified by Sierra Club v. Morton ${ }^{154}$ and Schlesinger v. Reservists Committee to Stop the War, ${ }^{155}$ focused upon a plaintiff's failure or inability to plead sufficient injury-infact distinguishable from some generalized loss suffered by the public at large. The second, exemplified by United States $v$. Richardson, ${ }^{156}$ denied

148. Schlesinger, 418 U.S. at 239 (Marshall, J., dissenting).

149. Id. at 239-40 (Marshall, J., dissenting).

150. Id. at 235 (Brennan, J., dissenting).

151. Id. at 236 (Brennan, J., dissenting). Thus, Justice Brennan agreed with Justice Stewart. See supra notes 143-44 and accompanying text.

152. Schlesinger, 418 U.S. at 236-37 (Brennan, J., dissenting). For that reason he declined to discuss whether the majority-rejected concept of citizen standing was appropriate. Id. at 237 (Brennan, J., dissenting).

153. Id. at 236 (Brennan, J., dissenting) (citations omitted). Justice Brennan did not indicate when he abandoned the Flast nexus requirement. In Flast, he had joined the Court's opinion. See Flast v. Cohen, 392 U.S. 83 (1968).

154. 405 U.S. 727 (1972); see supra notes $110-16$ and accompanying text.

155. 418 U.S. 208 (1974); see supra notes 133-42 and accompanying text.

156. 418 U.S. 166 (1974); see supra notes 120-32 and accompanying text. 
standing because the plaintiff failed to show a sufficient nexus between the harm he suffered and the constitutional right under which protection was claimed. ${ }^{157}$ The distinction between these two approaches is important. By the Court's own analysis, a finding of no injury-in-fact is a constitutional bar to federal court jurisdiction, whereas failure to meet the nexus requirement establishes only a prudential impediment to federal court action. ${ }^{158}$ The cases of the early 1970's focused far more on the first approach, a constitutional test that bodes ill for broader concepts of standing.

\section{Standing in the Mid-1970's}

In Warth $v$. Seldin, ${ }^{159}$ the Court employed both the injury-in-fact and nexus tests, but it did so more restrictively than in Sierra Club or Richardson. Warth was brought by a kaleidoscope of plaintiffs ${ }^{160}$ challenging a suburban zoning ordinance on the ground that it was tailored to exclude low- and moderate-income persons in violation of the Civil Rights Acts of 1870 and $1871 .{ }^{161}$ A bitterly divided Court held that none of the plaintiffs had standing. With respect to the low-income plaintiffs, the Court noted that although they had pleaded deliberate exclusion of low-income racial and ethnic minority groups by the zoning ordinance, the plaintiffs had not pleaded that they had been personally excluded. The Court held that the complaint, therefore, failed to plead the individual injury required under the Constitution to confer standing. ${ }^{162}$ The individual plaintiffs in Warth had pleaded injury to the group

157. Richardson, of course, involved both approaches; the Court found that the plaintiff had satisfied neither the injury-in-fact test nor the nexus test. See supra notes 120-29 and accompanying text.

158. See supra notes $9-15$ and accompanying text. Thus, in cases where the Court finds no injury-in-fact, one must either take issue with the Court's definition and application of that term or dispute the theory that the injury-in-fact requirement is based on article 1II's case and controversy language and is therefore jurisdictional. This Article urges the first of these two approaches. See infra Part III. The nexus requirement, by contrast, may be opposed either, as Professor Tribe has done, on the ground that it serves to deny standing when a decision on the merits would be preferable, see supra notes 19-20 and accompanying text, or on other nonconstitutional grounds, see infra Part III, Section $A$.

159. 422 U.S. 490 (1975).

160. The plaintiff group included low-income individuals desiring to move to the suburb; urban taxpayers claiming that their taxes were higher because the zoning ordinance caused the city to have more low-income residents in need of municipal services; a not-for-profit corporation formed to foster low-income housing opportunities; and several builders and housing associations who asserted an interest in creation of low-income housing in the suburb. Id. at 493-97, 503.

161. Id. at 493; see Civil Rights Acts of 1870 and 1871, 42 U.S.C. $\$ \S 1981-1983$ (1982).

162. Warth, 422 U.S. at 502-05. The Warth plaintiffs had sued as representatives of a class, $i d$. at $493 \mathrm{n} .1$, which presumably encompassed individuals who had been excluded. The Court, however, found that the absence of personal injury to the named individuals precluded them from relying upon injury to others, $i d$. at 502-05 (citing O'Shea v. Littleton, 414 U.S. 488 (1974) and Bailey v. 
of which they were members, unlike the plaintiff in Sierra Club, ${ }^{163}$ but the Court still found the pleading insufficient because the plaintiffs had not pleaded injury traceable to particular individuals. Warth, therefore, seemed to deny standing in a situation in which the Sierra Club Court apparently would not have. The Court, though recognizing that the de-

Patterson, 369 U.S. 31 (1962)), and thus implicitly held that such plaintiffs would not satisfy the typicality requirement of FED. R. CIV. P. 23(a).

During the 1970's and early 1980's, the Court developed a variation on the Sierra Club and Warth theme of inability to show personal injury. Under the variation, the Court looked to the likelihood of future personal injury in cases where the plaintiff sought injunctive, as opposed to legal, relief. For example, in City of Los Angeles v. Lyons, 461 U.S. 95 (1983), the plaintiff had been stopped for a traffic violation. He asserted that though he had not resisted, he had been choked by the arresting officer, causing him to lose consciousness and to suffer damage to his larynx. Id. at 9798. Evidence showed that Los Angeles police officers were trained in the use of two types of chokehold, id. at $97 \mathrm{n} .1$, that the officers were permitted to use chokeholds even when they were not threatened with injury or resistance, $i d$. at 99 , and that 16 persons had died from chokeholds applied by Los Angeles police officers. Id. at 115-16 (Marshall, J., dissenting).

The plaintiff sought damages and an injunction against future police use of such chokeholds. The Court held that the federal courts could not grant equitable relief because Lyons was unable to show any likelihood that he would be choked again, and therefore had not shown injury-in-fact. Id. at 105-06. Thus, the Court made clear that unless the government were to establish an unconstitutional policy in terms general enough to apply with certainty to any plaintiff, injunctive relief would never be available because a plaintiff would be unable to show a sufficient likelihood of future harm to him, even though it might be obvious that such harm would occur to large numbers of people. See id. This result, according to the majority, was not new doctrine; it merely reflected the Court's earlier decisions in Rizzo v. Goode, 423 U.S. 362 (1976), and O'Shea v. Littleton, 414 U.S. 488 (1974), both of which involved challenges to official practices alleged to be unconstitutional and racially motivated. See Lyons, 461 U.S. at 102-05.

Justice Marshall, joined in dissent by Justices Brennan, Blackmun and Stevens, charged that the majority's reliance upon $O$ 'Shea and Rizzo was misplaced because neither case had involved specific plaintiffs' allegations of past injury to themselves in addition to the need for prospective equitable relief. Id. at 113, 123-24 (Marshall, J., dissenting). Justice Marshall also assailed the Court for "fragmenting the standing inquiry and imposing a separate standing hurdle with respect to each form of relief sought." Id. at 127 (Marshall, J., dissenting). He argued that the Court should focus instead upon whether a plaintiff has standing to litigate a claim, as distinct from whether, having presented his claim, he is entitled to a particular form of relief. Id. Finally, Justice Marshall pointed out that the federal courts were powerless in a constitutional system restrained by a Lyons concept of standing:

The Court's decision removes an entire class of constitutional violations from the equitable powers of a federal court. It immunizes from prospective equitable relief any policy that authorizes persistent deprivations of constitutional rights as long as no individual can establish with substantial certainty that he will be injured, or injured again, in the future. The CHIEF Justice asked in Bivens v. Six Unknown Fed. Narcotics Agents, 403 U.S. 388 . . . (1971) (dissenting opinion), "what would be the judicial response to a police order authorizing "shoot to kill' with respect to every fugitive?" His answer was that it would be "easy to predict our collective wrath and outrage." We now learn that wrath and outrage cannot be translated into an order to cease the unconstitutional practice, but only an award of damages to those who are victimized by the practice and live to sue and to the survivors of those who are not so fortunate. Under the view expressed by the majority today, if the police adopt a policy of "shoot to kill," or a policy of shooting 1 out of 10 suspects, the federal courts will be powerless to enjoin its continuation. . . . The federal judical power is now limited to levying a toll for such a systematic constitutional violation.

Id. at 137 (Marshall, J., dissenting) (citations omitted).

163. Sierra Club v. Morton, 405 U.S. 727 (1972); see supra notes 110-16 and accompanying text. 
fendant's actions might have increased housing costs in the suburb, also refused to find a causal link between those actions and the plaintiffs' exclusion. ${ }^{164}$ Finally, the majority characterized the harm to the individual plaintiffs as too speculative and remote. ${ }^{165}$

Regarding the taxpayer plaintiffs, the Court found that even were they able to satisfy the injury-in-fact test, ${ }^{166}$ they would be relying upon violations of the rights of others who were discriminated against in housing rather than upon their own rights. The Court found that the taxpayers failed the nexus test. ${ }^{167}$ Similar reasoning was used to deny standing to the associations claiming that the exclusion of certain groups from the suburb caused them economic injury. ${ }^{168}$ Finally, the Court found that the builders association, which sought damages, alleged no pecuniary loss to itself and could not recover on behalf of its members. Its claim for prospective relief was barred because there were no allegations of current building projects being frustrated by the zoning ordinance. ${ }^{169}$ Thus, the Court used the two-part test to deny standing to all of the plaintiffs. ${ }^{170}$

Simon v. Eastern Kentucky Welfare Rights Organization ${ }^{171}$ continued the Court's increasingly restrictive view of standing by requiring that the causal link between government's wrongful act and plaintiff's injury be precisely pleaded. The plaintiff, a coalition of indigent individuals seeking hospital care and organizations representing indigents' interests,

164. Warth, 422 U.S. at 504-07.

165. Id. at 507.

166. Id. at 509. The taxpayer plaintiffs asserted that the exclusion of low-and middle-income residents from the suburb placed a greater burden on the municipality to provide tax abatements for low- and moderate-cost housing. This, in turn, was alleged to increase the tax burden of city residents in order to finance essential public services. Id. at 508-09.

167. Id. at 509-10.

168. Id. at 512-14.

169. Id. at 515-17. In this respect, the Court paralleled its treatment of Sierra Club's claim in Sierra Club v. Morton, 405 U.S. 727 (1972). See supra notes 110.16 and accompanying text.

170. Justice Brennan, dissenting, argued that three of the groups of plaintiffs clearly had standing. Warth, 422 U.S. at 521 (Brennan, J., dissenting). First, he would have granted standing to the low-income and minority plaintiffs because their complaint alleged sufficient, specific instances of concrete injury suffered as a result of the exclusionary practices of defendants. Id. at 523-26 (Brennan, J., dissenting). Second, with respect to the two organizational plaintiffs, he would have found their "allegations of past injury, which members of both these organizations have clearly made, and of a future intent, if the barriers are cleared, again to develop suitable housing" sufficient to demonstrate the "requisite personal stake in the outcome of this controversy." Id. at 530 (Brennan, J., dissenting) (emphasis in original).

Justice Brennan then pointed out that in order to deny standing, the majority had demanded first, that the low-income and minority plaintiffs plead an unprecedented, "unachievable specificity" in showing the nexus between defendants' actions and plaintiff' alleged injury, id. at 528 (Brennan, J., dissenting), and second, that the organizational plaintiffs "allege the (economically) impossible"-specific concrete injuries with respect to a particular, current project, id. at 530 (Brennan, J., dissenting). Justice Brennan concluded that the Court's disposition of the case reflected its unexpressed feelings on the merits more than it reflected any principled analysis of standing concepts. See infra note 263 .

171. 426 U.S. 26 (1976). 
challenged a newly modified Internal Revenue Service ruling that allegedly encouraged hospitals to refuse care to indigent patients while allowing the hospitals to retain their status as charitable organizations. The organization argued that the ruling violated congressional intent embodied in the Internal Revenue Code's provision exempting charitable organizations from taxation. The Court held that the organization lacked standing on the narrow but significant ground that it had failed to establish that the revenue ruling had caused the hospitals to deny treatment to its members. ${ }^{172}$ The plaintiff was, therefore, unable to demonstrate that a favorable judgment would redress the harm that its members had suffered. ${ }^{173}$

Justice Brennan concurred in the judgment on the ground that the plaintiff had failed to show that the hospitals denying the plaintiff coalition's members treatment were within the ambit of the modification wrought by the challenged ruling. ${ }^{174}$ But he sharply criticized what he viewed as an addition to the injury-in-fact test by the majority:

Nothing in the logic or policy of constitutionally required standing is added by the further injury-in-fact dimension required by the Court today-that respondents allege that the hospitals affecting them would not have elected to forgo the favorable tax treatment and that this would "result in the availability to respondents of" free or below-cost medical services. ${ }^{175}$

Thus, Justice Brennan repudiated the heightened causality requirement used by the Court in Linda R.S. v. Richard D. ${ }^{176}$

172. Id. at 41-43. "It is purely speculative whether the denials of service specified in the complaint fairly can be traced to petitioners' 'encouragement' or instead result from decisions made by the hospitals without regard to the tax implications." Id. at 42-43.

The problem in Simon was not one of pleading, as Justice Brennan made clear in his concurring opinion. Defendants sought summary judgment on the question of standing, specifically attacking the causation question. Id. at 53 (Brennan, J., concurring). As Justice Brennan noted,

At this point in the litigation, it was clearly incumbent upon the respondents to make a showing sufficient to create a material issue of fact whether there was any connection between the hospitals affecting them and the Ruling alleged to be illegally "encouraging" taxexempt hospitals to withdraw the provision of indigents' services, thereby injuring respondents" "opportunity and ability" for such services. . . . No such showing was made. There is absolutely no indication in the record that the contested Ruling altered the operation of these hospitals in any way....

Id. at 53-54 (Brennan, J., concurring) (citation omitted).

173. In this respect, the Court echoed its opinion in Linda R.S. v. Richard D., 410 U.S. 614, 617-18 (1973). See supra notes $117-19$ and accompanying text.

174. Simon, 426 U.S. at 47-50, 53-54 (Brennan, J., concurring).

175. Id. at 56 (Brennan, J., concurring). Justice Brennan was referring to the majority's assertion that:

[i]t is equally speculative whether the desired exercise of the court's remedial powers in this suit would result in the availability to respondents of such services. So far as the complaint sheds light, it is just as plausible that the hospitals to which respondents may apply for service would elect to forgo favorable tax treatment . . . .

Id. at 43 .

176. 410 U.S. 614 (1973); see supra notes 117-19 and accompanying text. 
It is unclear in the aftermath of Simon whether the new twist to the injury-in-fact test that Justice Brennan criticized has actually become a permanent part of constitutional concepts of standing. Certainly the new factor was not necessary to the decision in Simon, and therefore it may be regarded as dictum. ${ }^{177}$ If so, however, it was the dictum of at least six members of the Court, ${ }^{178}$ and thus it may play a role in future decisions.

\section{Standing to Raise Fourth Amendment Claims}

Beginning in 1978, the Court decided a series of fourth amendment cases that radically changed the concept of standing in that area. The seminal case was Rakas $v$. Illinois, ${ }^{179}$ where passengers in a vehicle that was stopped and searched were held to lack standing under the fourth amendment to challenge the search. The Court eviscerated a doctrine under which anyone legitimately on searched private premises had standing to challenge the search. ${ }^{180}$ Instead, the Court said that the standing inquiry was whether the defendant's own fourth amendment right of privacy had been invaded by the search. ${ }^{181}$ At the same time, the majority, led by Justice Rehnquist, announced that the vocabulary of standing would no longer be used in fourth amendment cases.

[T]he question necessarily arises whether it serves any useful analytical purpose to consider this principle a matter of standing, distinct from the merits of a defendant's Fourth Amendment claim. ... [W]e think the better analysis forthrightly focuses on the extent of a particular defendant's rights under the Fourth Amendment, rather than on any theoretically separate, but invariably intertwined concept of standing. ${ }^{182}$

Despite this language, Justice Rehnquist insisted that the new approach would result in no doctrinal change. ${ }^{183}$ Nonetheless, Rakas had the effect of denying standing to a defendant who clearly would have had it in prior years.

177. The plaintiffs failed to show that the hospitals had refused service because of the ruling and not because of other factors. Since they made no such showing of causality, plaintiffs lacked standing. Therefore, the Court never had to examine, under some lieightened causality requirement, whether the hospitals would actually provide the services if the ruling were overturned rather than deny the services and forgo the tax advantages. See also Allen v. Wright, $105 \mathrm{~S}$. Ct. 51 (1984), in which the Court reiterated the reasoning of Simon, again as dictum, in denying standing to parents of black school children seeking to challenge Internal Revenue Service tax-exempt status conferred upon allegedly discriminatory private schools.

178. Justice Marshall joined Justice Brennan's concurrence. Justice Stevens did not participate in the case. Simon, 426 U.S. at 28.

179. 439 U.S. 128 (1978).

180. Jones v. United States, 362 U.S. 257, 365-67 (1960), overruled by United States v. Salvucci, 448 U.S. 83, 85 (1980).

181. Rakas, 439 U.S. at $138-40$.

182. Id. at 138-39.

183. Id. at 139. 
The trend begun in Rakas continued in United States v. Salvucci, ${ }^{184}$ Rawlings v. Kentucky, ${ }^{185}$ and United States v. Payner, ${ }^{186}$ each of which denied defendants standing to challenge fourth amendment searches that they would have been able to attack before Rakas. ${ }^{187}$ Review of these cases makes it clear that Rakas, Salvucci, Rawlings, and Payner all had demonstrated injury-in-fact: the government proposed to introduce material seized in contravention of the fourth amendment in evidence against the defendants. The Court denied standing, however, because it found that the defendants were asserting someone else's fourth amendment privacy interest, not their own. ${ }^{\text {188 }}$ In essence, the Court raised the same objection to standing in the fourth amendment context as in Warth v. Seldin: ${ }^{189}$ defendants in the fourth amendment cases were said to lack standing because they could not connect the injury they unquestionably suffered with a personal constitutional right. In this sense, they failed to satisfy the nexus test. ${ }^{190}$ Close reading of the fourth amendment standing cases reveals that the Court has retreated to use of the legally-protected-interest test, which it had repudiated explicitly in 1970 in Association of Data Processing Service Organizations v. Camp. ${ }^{191}$ Indeed, this may be the reason that Justice Rehnquist was so eager to abandon standing terminology in fourth amendment standing cases; to do otherwise would have made the inconsistency clearer. ${ }^{192}$

\section{The Decision in Valley Forge}

The Court's most recent consideration of taxpayer and citizen standing came in Valley Forge Christian College v. Americans United for Separation of Church and State, Inc. ${ }^{193}$ The Court denied standing to a nonprofit taxpayer organization and four of its employees who argued

184. 448 U.S. 83 (1980).

185. 448 U.S. 98 (1980).

186. 447 U.S. 727 (1980).

187. For a detailed description of these cases, see Doernberg, supra note 29; see also Burkoff, The Court That Devoured the Fourth Amendment: The Triumph of an Inconsistent Exclusionary Doctrine, 58 Or. L. REv. 151 (1979); Mickenberg, Fourth Amendment Standing After Rakas v. Illinois: From Property to Privacy and Back, 16 NEw ENG. L. REV. 197 (1981).

188. Rawlings v. Kentucky, 448 U.S. 98, 105 (1980); United States v. Salvucci, 448 U.S. 83, 95 (1980); United States v. Payner, 447 U.S. 727, 732 (1980); Rakas v. Illinois, 439 U.S. 128, 133-34 (1978); accord Alderman v. United States, 394 U.S. 165, 174 (1969) ("What petitioners appear to assert is an independent constitutional right of their own to exclude relevant and probative evidence because it was seized from another in violation of the Fourth Amendment.").

189. 422 U.S. 490 (1975); see supra notes $159-70$ and accompanying text.

190. See supra text accompanying notes 9-10.

191. 397 U.S. 150, 153-54 (1970); see infra notes 214-26 and accompanying text. Justice Brennan interprets Flast v. Cohen, 392 U.S. 83 (1968), as having abandoned this legally-protected-interest test. See infra note 225 and accompanying text.

192. See generally Burkoff, supra note 187; Doernberg, supra note 29; Mickenberg, supra note 187.

193. 454 U.S. 464 (1982). 
that conveyance of a parcel of land by the federal government to Valley Forge Christian College violated the establishment clause. The five-tofour majority held that, although plaintiffs had alleged " 'depriv[ation] of the fair and constitutional use of [their] tax dollar," "194 they nonetheless had failed to demonstrate injury-in-fact. ${ }^{195}$

The Court based its conclusion on two grounds. First, the Court seemed to return to the limitation on taxpayer standing first announced in Frothingham v. Mellon. ${ }^{196}$ It limited Flast v. Cohen, ${ }^{197}$ a case allowing taxpayer standing, to challenges of congressional, rather than executive, action. ${ }^{198}$ Second, the Court found that the plaintiffs, as taxpayers, were not challenging any exercise of power under the taxing and spending clause $^{199}$ (as was the case in Flast), but rather were objecting to the subsequent disposition of property that the plaintiffs conceded the government had lawfully acquired through expenditure of tax funds. ${ }^{200}$

The majority also attacked the lower court's decision to allow the plaintiffs standing as citizens. The Third Circuit had noted that the plaintiffs' real interest was not as taxpayers, but as persons interested in maintaining the rigorous separation of church and state. ${ }^{201}$ The majority sharply criticized the assertion that the plaintiffs had shown sufficient violation of personal constitutional rights rather than generalized citizen grievances, which the Court in the past had found insufficient to confer standing.

194. Valley Forge, 454 U.S. at 476 (quoting Respondent's Amended Complaint at app. 10).

195. Id. at 485 .

196. 262 U.S. 447 (1923).

197. 392 U.S. 83 (1968).

198. Valley Forge, 454 U.S. at 479. In dissent, Justice Brennan took sharp issue with this reading of Flast, accusing the majority of "wrenching snippets of language from our opinions," and of creating "tortuous distinctions ... . [that] are specious, at best: at worst, . . . pernicious to our constitutional heritage." Id. at 510 (Brennan, J., dissenting). He went on to rebuke the Court for artificially limiting Flast to challenges of Congressional power, noting that in Flast, the plaintifis challenged executive action of the Department of Health, Education and Welfare pursuant to authority granted by Congress, precisely as in Valley Forge. Id.

199. U.S. CoNST. art. I, $\S 8$, cl. 1 .

200. Valley Forge, 454 U.S. at 480 \& n.17.

201. Americans United for Separation of Church \& State, Inc. v. Department of Health, Educ. \& Welfare, 619 F.2d 252, 261 (3d Cir. 1980), rev'd sub nom. Valley Forge Christian College v. Americans United for Separation of Church \& State, Inc., 454 U.S. 464 (1982). The Supreme Court majority relied upon the Court of Appeals' own opinion to support the majority's argument that the plaintiffs were not entitled to standing as taxpayers. The Court of Appeals had analyzed plaintiffs' true interest, cutting through the verbiage imposed upon them by previous standing cases to deal explicitly with their actual concern.

Plaintiffs have no reason to expect, nor perhaps do they care about, any personal tax saving that might result should they prevail. The crux of the interest at stake, the plaintiffs argue, is found in the Establishment Clause, not in the supposed loss of money, as such. As a matter of primary identity, therefore, the plaintiffs are not so much taxpayers as separationists ....

619 F.2d at 261. 
This reasoning process merely disguises, we think with a rather thin veil, the inconsistency of the [lower] court's results with our decisions in Schlesinger and Richardson. . . . [A]ssertion of a right to a particular kind of Government conduct, which the Government has violated by acting differently, cannot alone satisfy the requirements of Art. III without draining those requirements of meaning. ${ }^{202}$

At the same time, the majority recognized the possibility that under its analysis, cases might arise in which no one would have standing.

Respondents' claim of standing implicitly rests on the presumption that violations of the Establishment Clause typically will not cause injury [to anyone] sufficient to confer standing under the "traditional" view of Art. III. But "[ $t]$ he assumption that if respondents have no standing to sue, no one would have standing, is not a reason to find standing."203

This Article suggests, contrary to the Court's implication, that the absence of standing for any possible plaintiff is indeed a matter for concern. Such an absence of possible plaintiffs may not, of course, by itself be a reason to allow standing. It is, however, a matter of some gravity if situations exist where the government may, with impunity, violate the Constitution because no one is able to challenge the government's action in court. $^{204}$

Justice Brennan's vehement dissent traced the development of taxpayer standing doctrine and then argued that rights under the establishment clause are personal rights specifically designed, at least in part, to protect taxpayers. $^{205}$ Brennan also criticized Frothingham v. Mellon, ${ }^{206}$ the seminal taxpayer standing case. He questioned its "obscure" reasoning and implicitly challenged Frothingham's reliance upon the indirectness of the connection between the taxpayer's remittance and the government's expenditure. ${ }^{207}$ "Frothingham also stressed the indirectness of the taxpayer's injury. But, as a matter of Art. III standing, if the causal relationship is sufficiently certain, the length of the causal chain is irrelevant."208

In fact, Justice Brennan noted that Frothingham contained an "unstated premise," which had been identified in Justice Harlan's Flast dissent: the notion that taxpayer standing, if it existed at all, should be based on citizens' generalized grievances concerning government actions,

202. Valley Forge, 454 U.S. at 483 .

203. Id. at 489 (quoting Schlesinger v. Reservists Comm. to Stop the War, 418 U.S. 208, 227 (1974)).

204. See generally infra Part III.

205. Valley Forge, 454 U.S. at 500-05 (Brennan, J., dissenting). "It is clear . . . that one of the primary purposes of the Establishment Clause was to prevent the use of tax moneys for religious purposes." Id. at 504 (Brennan, J., dissenting).

206. 262 U.S. 447 (1923).

207. Valley Forge, 454 U.S. at 496 (Brennan, J., dissenting).

208. Id. at 497 (Brennan, J., dissenting) (emphasis in original) (footnote omitted). 
rather than on some mythical injury-in-fact attributable to an individual taxpayer. ${ }^{209}$ In support of that notion, Brennan argued that Flast was a special case, applicable only to taxpayer claims involving the first amendment religion clauses and not to standing generally. ${ }^{210}$ Justice Brennan then argued that establishment clause cases themselves are special cases for taxpayer standing purposes. ${ }^{211}$

It may be that Congress can tax for almost any reason, or for no reason at all. There is, so far as I have been able to discern, but one constitutionally imposed limit on that authority. Congress cannot use tax money to support a church, or to encourage religion. That is "the forbidden exaction." . . . In absolute terms the history of the Establishment Clause of the First Amendment makes this clear. History also makes it clear that the federal taxpayer is a singularly "proper and appropriate party to invoke a federal court's jurisdiction" to challenge a federal bestowal of largesse as a violation of the Establishment Clause. Each, and indeed every, federal taxpayer suffers precisely the injury that the Establishment Clause guards against when the Federal Government directs that funds be taken from the pocketbooks of the citizenry and

209. Id. at 498 (Brennan, J., dissenting). Indeed, Justice Harlan's entire dissent was based upon that unstated premise:

[The] taxpayer's complaint can consist only of an allegation that public funds have been, or shortly will be, expended for purposes inconsistent with the Constitution. The taxpayer cannot ask the return of any portion of his previous tax payments, cannot prevent the collection of any existing tax debt, and cannot demand an adjudication of the propriety of any particular level of taxation. His tax payments are received for the general purposes of the United States, and are, upon proper receipt, lost in the general revenues.

Flast v. Cohen, 392 U.S. 83, 128 (1968) (Harlan, J., dissenting). Earlier in the opinion, Justice Harlan had discussed this problem in more explicit terms:

[Tlaxpayers' interests in the expenditure of public funds [are not] differentiated from those of the general public by any special rights retained by them in their tax payments. The simple fact is that no such rights can sensibly be said to exist. . . . The national legislature is required by the Constitution to exercise its spending powers to "provide for the common Defence and general Welfare." Art. I, $\S 8, \mathrm{cl}$. 1 . Whatever other implications there may be to that sweeping phrase, it surely means that the United States holds its general funds, not as stakeholder or trustee for those who have paid its imposts, but as surrogate for the population at large. Any rights of a taxpayer with respect to the purposes for which those funds are expended are thus subsumed in, and extinguished by, the common rights of all citizens. To characterize taxpayers' interests in such expenditures as proprietary or even personal either deprives those terms of all meaning or postulates for taxpayers a scintilla juris in funds that are no longer theirs. . . . We must recognize that these non-Hohfeldian plaintiffs complain, just as the petitioner in Frothingham sought to complain, not as taxpayers, but as "private attorneys-general." The interests they represent, and the rights they espouse, are bereft of any personal or proprietary coloration. They are, as litigants, indistinguishable from any group selected at random from among the general population, taxpayers and nontaxpayers alike.

Id. at 118-20 (Harlan, J., dissenting) (footnote omitted).

This Article does not disagree with Justice Harlan's characterization, but argues instead that in certain circumstances it is appropriate to adopt a broader concept of standing, consistent with the existence of such collectively shared interests, as the only effective available means to correct governmental wrongs. See infra Part III.

210. Valley Forge, 454 U.S. at 507-08 (Brennan, J., dissenting).

211. Id. at 509 (Brennan, J., dissenting). 
placed into the coffers of the ministry. ${ }^{212}$

Thus, Justice Brennan realized that some claims of government misbehavior are not amenable to adjudication under traditional standing doctrine. But instead of insisting in procrustean fashion, as the majority did, that cases should be made to fit the standing doctrine, Justice Brennan implicitly suggested that the doctrine should be modified to fit the cases so that the judiciary could redress government wrongs. By the time $\mathrm{Val}$ ley Forge was decided, however, a decade of Supreme Court standing decisions had made it clear that access to the federal courts in constitutional cases was far more limited. ${ }^{213}$ Yet the trend toward narrower standing was not without its interruptions, as the next Section demonstrates.

\section{B. Grants of Standing}

The Court began the 1970's by distinguishing questions of standing from questions involving the merits. In Association of Data Processing Service Organizations, Inc. v. Camp, ${ }^{214}$ the Court considered a private corporation's challenge to a ruling of the Comptroller of the Currency that permitted banks to make nonbanking data-processing services available to other banks and bank customers. The plaintiff alleged that the ruling violated the Bank Service Corporation $\mathrm{Act}^{215}$ and permitted banks

212. Id. (emphasis in original) (citations omitted) (quoting Everson v. Board of Educ., 330 U.S. 1, 45 (1947) (Rutledge, J., dissenting) and Flast v. Cohen, 392 U.S. 83, 103 (1968)). At the same time, Justice Brennan noted the practical impossibility of a taxpayer challenge at the time of collection of the funds, rather than when they are disbursed. This, he argued, militates in favor of a subsequent establishment clause challenge even though a successful challenge may not directly benefit the taxpayer-plaintif's pocketbook. Id. at 509-10 (Brennan, J., dissenting).

213. Standing is not the only device that the Supreme Court used to narrow the availability of a federal forum for consideration of constitutional challenges during the 1970's. In a series of cases beginning in 1971, the Court announced the reemergence of a federal abstention doctrine based on considerations of comity, equity, and federalism. Under the doctrine, federal courts could not consider constitutional questions arising in state criminal proceedings, except at the Supreme Court level pursuant to 28 U.S.C. $\S 1257$ (1982), when such questions could be decided by the state tribunals themselves. The doctrine's purpose was to avoid undue interference with state criminal justice systems. Younger v. Harris, 401 U.S. 37 (1971). As the decade progressed, this bar to federal action expanded to cases where the state proceeding was only quasi-criminal, see Huffman v. Pursue, Ltd., 420 U.S. 592 (1975), to some cases where the federal proceeding commenced before the state criminal proceeding, see Hicks v. Miranda, 422 U.S. 332 (1975), to cases where there was no state criminal proceeding pending at all, see Rizzo v. Goode, 423 U.S. 362 (1976), and finally to cases where the state proceeding was clearly civil, see Moore v. Sims, 442 U.S. 415 (1979); Trainor v. Hernandez, 431 U.S. 434 (1977). The Younger doctrine and the Supreme Court's reluctance to permit the federal courts to enforce federal constitutional guarantees have been sharply criticized. See, e.g., Zeigler, $A$ Reassessment of the Younger Doctrine in Light of the Legislative History of Reconstruction, 1983 DUKE L.J. 987. In all of the Younger line of cases, the plaintiffs clearly had standing, but the Court employed other justiciability doctrines in order to deny them access to the federal courts.

214. 397 U.S. 150 (1970).

215. Bank Service Corporation Act, 12 U.S.C. $\$ 1864$ (1962) (significantly amended 1982): "No bank service corporation may engage in any activity other than the performance of bank services for banks." 
to compete unlawfully with nonbanking organizations. The district court dismissed the action for lack of standing and the court of appeals affirmed. ${ }^{216}$

The Supreme Court used Camp to clarify the injury-in-fact requirement. The Court easily found that the plaintiff had demonstrated injuryin-fact. The anticipated loss of future business to competing banks, plus the plaintiff's allegations that present customers had been lured away by a particular bank, constituted sufficient injury. In so holding, the Court rejected the court of appeals' requirement of injury to some legally recognized interest of the individual-an interest conferred by statute or contract-or to some public interest where the plaintiff's standing was congressionally recognized. ${ }^{217}$ "The 'legal interest' test goes to the merits. The question of standing is different."218 The plaintiff need only show that he was in the "zone of interests" protected by the statute. The unanimous Court went on to emphasize that the interest need not be economic, but that it might reflect " 'aesthetic, conservational, and recreational' as well as economic values."219 The Court thus took an expansive view of the injury-in-fact test and did not require that the plaintiff allege a violation of a law designed for his protection, as required by the nexus test. In these respects, the Camp Court was far more liberal than

216. Association of Data Processing Serv. Orgs., Inc. v. Camp, 279 F. Supp. 675 (D. Minn. 1968), affd, 406 F.2d 837 (8th Cir. 1969), rev'd, 397 U.S. 150 (1970).

217. Camp, 397 U.S. at 153. Thus, under the legally-protected-interest test, the plaintiff would have had to show that the Bank Service Corporation Act's restriction, see supra note 215, was intended to protect its members from increased competition or that they had some common law or constitutional right to be free from such competition. See Note, The Supreme Court, 1969 Term, 84 HARv. L. REv. 1, 177-81 (1970). The absence of such a right would have deprived the plaintiff of standing. Under the test adopted in Camp, it was sufficient that the plaintiff was injured by defend. ant's failure to require banks to operate within the restrictions of the Act, since such operation would have, as a practical matter, relieved the plaintiff of the burden of competition from banks.

218. Camp, 397 U.S. at 153. In Barlow v. Collins, 397 U.S. 159 (1970), decided with Camp, the Court reiterated the disutility of the legal interest test. Barlow was brought by tenant farmers clial. lenging an amendment to a Department of Agriculture regulation that dealt with assignments of funds received pursuant to the Soil Conservation and Domestic Allotment Act, 16 U.S.C. $\$ 590 \mathrm{~h}(\mathrm{~g})$ (1982). The lower courts ruled that the plaintiffs lacked standing because no legally protected interest had been invaded. Barlow, 397 U.S. at 163-64. The Court rejected this narrow view of standing, and held that the plaintiffs were "within the zone of interests protected by the Act," id. at 164, because there clearly had been congressional intent to benefit tenant farmers. 1d. at 164-65. The Court did not, however, elaborate on the extent to which the "zone of interests" concept was broader than the "legally protected interests" concept.

219. Camp, 397 U.S. at 154 (quoting Office of Communication of United Church of Christ $v$. FCC, 359 F.2d 994, 1000-06 (D.C. Cir. 1966); Scenic Hudson Preservation Conference v. Federal Power Comm'n, 354 F.2d 608, 616 (2d Cir. 1965)). Interestingly, thc Court noted in dictum that "[a] person or a family may have a spiritual stake in First Amendment values sufficient to give standing to raise issues concerning the Establishment Clause and the Free Exercise Clause." Id. (citing Abington School Dist. v. Schempp, 374 U.S. 203 (1963)). The assertion is clearly at odds with the Court's subsequent disposition of Valley Forge Christian College v. Americans United for Separation of Church \& State, Inc., 454 U.S. 464 (1982). See supra notes 193-212 and accompanying text. 
the Courts that later decided Valley Forge, Schlesinger, and Richardson. ${ }^{220}$

Justice Brennan concurred in the results of Camp and the companion case of Barlow v. Collins, ${ }^{221}$ but disagreed with the Court's standing analysis. He noted that the Court used a two-step inquiry in Camp, asking first whether plaintiff had suffered injury-in-fact and second whether the interest asserted was within the zone of protected interests. ${ }^{222}$ But, he argued, the second step was inappropriate to standing analysis since it looked to the merits of the controversy or to its general justiciability. ${ }^{223}$

I had thought we discarded the notion of any additional requirement when we discussed standing solely in terms of its constitutional content in Flast v. Cohen . . . By requiring a second, nonconstitutional step, the Court comes very close to perpetuating the discredited requirement that conditioned standing on a showing by the plaintiff that the challenged governmental action invaded one of his legally protected interests. ${ }^{224}$

Justice Brennan's reading of Flast finds some support in his quotation of that case. The Flast majority had declared that "when standing is placed in issue in a case, the question is whether the person whose standing is challenged is a proper party to request an adjudication of a particular issue' and not [according to Justice Brennan] . . . whether on the merits, the plaintiff has a legally protected interest that the defendant's action invaded."225 Flast was not as clear, however, as Justice Brennan's assertion made it seem. The Court's exclusion of the legally-protectedinterest test in Flast was implicit rather than explicit.

Nonetheless, Camp initiated two liberal trends in the standing area: repudiation of the legally-protected-interest test in favor of the zone-ofinterest analysis, and Justice Brennan's strong assertion that the only appropriate inquiry was directed to injury-in-fact. Professor Davis regards Camp as a watershed opinion.

In Data Processing . . . the Supreme Court unanimously superceded a large batch of law [holding] ... that something in the nature of a "legal right" or "legal interest" was necessary for standing. That shift is a great accomplishment and it deserves strong emphasis, for federal law of standing now has a new and better orientation. But that much is no

220. See supra notes 120-49, 193-212 and accompanying text.

221. 397 U.S. 159 (1970); see supra note 218.

222. Barlow, 397 U.S. at 167-68 (Brennan, J., concurring and dissenting).

223. Id. at 168-69 (Brennan, J., concurring and dissenting).

224. Id. at 168 (Brennan, J., concurring and dissenting) (footnote omitted) (distinguishing Associated Indus. v. Ickes, 134 F.2d 694, 700 (2d Cir. 1943) (relying upon the legally protected interest test)).

225. Id. at 171 (Brennan, J., concurring and dissenting) (quoting Flast v. Cohen, 392 U.S. 83, 99-100 (1968)). 
longer a live issue, for it has been fully resolved by a unanimous Court. ${ }^{226}$

The Court seemed to reaffirm its liberal movement two years later in Trafficante v. Metropolitan Life Insurance Co. ${ }^{227}$ in which residents of a housing complex charged that the landlord had violated the Civil Rights Act of $1968^{228}$ by discriminating against nonwhite applicants. The lower courts dismissed the complaint on the ground that only victims of discrimination had standing. ${ }^{229}$ A unanimous Court reversed, finding that the statute defined an aggrieved person as one "who claims to have been injured by a discriminatory housing practice."230 The Trafficante plaintiffs claimed to have suffered loss of social and business opportunities and imposition of a stigma by being residents of a "white ghetto."231 The Court found that these claims constituted injury-in-fact and that they were sufficiently pleaded to establish the individualized injury ${ }^{232}$ absent in Sierra Club v. Morton. ${ }^{233}$ The Court also noted that Congress had broadened the concept of "persons aggrieved," making them private attorneys general-a classification the Court regarded as "not uncommon in modern legislative programs."234 Finally, the Court noted how broad a concept of standing it was willing to consider, at least in civil rights cases: "The person on the landlord's blacklist is not the only victim of discriminatory housing practices; it is, as Senator Javits said in supporting the bill, 'the whole community.' "235

In Trafficante, the Court implicitly propounded several notions about standing. First, it reaffirmed the Camp view that injury-in-fact might be noneconomic. ${ }^{236}$ Second, its reversal of the lower courts' dis-

226. Davis, supra note 21, at 457 (footnote omitted). Professor Davis' view that Camp settled the issue, however, now appears to have been overly optimistic, at least in the fourth amendment area, where the Court has sub silentio returned to the old standard. See supra notes 179-92 and accompanying text.

227. 409 U.S. 205 (1972).

228. 42 U.S.C. $\$ \$ 3601-3619$ (1982).

229. Trafficante v. Metropolitan Life Ins. Co., 322 F. Supp. 352, 353 (N.D. Cal.), affd, 446 F.2d 1158, 1164 (9th Cir. 1971), rev'd, 409 U.S. 205, 208 (1972). The lower courts viewed the plaintiffs as asserting third-party rights, perhaps anticipating the Court's position in Warth v. Seldin, 422 U.S. 490 (1975). See supra notes 166-67 and accompanying text; see also Warth, 422 U.S. at 514.

230. 42 U.S.C. $\$ 3610$ (a) (1982).

231. Trafficante, 409 U.S. at 208.

232. Id. at 209.

233. 405 U.S. 727 (1972); see supra notes 110-16 and accompanying text.

234. Trafficante, 409 U.S. at 211 (citing Perkins v. Matthews, 400 U.S. 379, 396 (1971); Allen v. State Bd. of Elections, 393 U.S. 544, 556 (1969); Newman v. Piggie Park Enters., 390 U.S. 400, 402 (1968); J.I. Case Co. v. Borak, 377 U.S. 426, 432 (1964)). The applicability of the private-attorneygeneral concept to the problems of standing is discussed infra in notes $367-73$ and accompanying text.

235. Trafficante, 409 U.S. at 211 (quoting I14 CoNG. Rec. 2706 (1968)). The Court stated, "We can give vitality to [the Act] only by a gencrous construction which gives standing to sue to all in the same housing unit who are injured by racial discrimination in the management of those facilities within the coverage of the statute." Id. at 212 .

236. See supra note 219 and accompanying text. 
missal implied that an individual might be injured for standing purposes by unlawful conduct directed at someone else. Third, and most important, it explicitly recognized that a legislative enactment might consider the whole community to be the benefited class, and that in such circumstances, members of the benefited community ought to have standing to challenge a violation of the enactment. ${ }^{237}$

The Court expanded its consideration of standing related to alleged noneconomic injury in United States $v$. $S C R A P,{ }^{238}$ in which an environmental group challenged an Interstate Commerce Commission ruling permitting railroads to levy a surcharge for transportation of recyclable commodities. ${ }^{239}$ The plaintiff organization alleged that the ruling discouraged use of recyclable goods, and thus had an adverse impact on the environment. Unlike the plaintiff in Sierra Club v. Morton, ${ }^{240}$ the $S C R A P$ plaintiff had pleaded a threat to its members' own enjoyment of the environment. ${ }^{241}$ At the same time, the Court recognized that the injury alleged in $S C R A P$ was not nearly so limited in scope as that involved in Sierra Club.

But we have already made it clear that standing is not to be denied simply because many people suffer the same injury. . . . To deny standing to persons who are in fact injured, simply because many others are also injured would mean that the most injurious and widespread Government actions could be questioned by nobody. We cannot accept that conclusion. $^{242}$

Thus, the Court specifically acknowledged that the existence of widespread public noneconomic injury might suggest the absence of standing under the rubric of "generalized grievances" mentioned in United States v. Richardson. ${ }^{243}$ At the same time, the Court deliberately affirmed the necessity of finding standing in such cases.

In Craig v. Boren, ${ }^{244}$ the Court went a step further in a case involv-

237. The Court reaffirmed the Trafficante decision in Gladstone, Realtors v. Village of Bellwood, 441 U.S. 91 (1979), again giving an extremely broad reading to the word "aggrieved" in Title VIII of the Civil Rights Act of 1968, 42 U.S.C. $\$ \S 3601-3619$ (1982). In that case, the Court found that members of the community, not themselves discriminated against, nevertheless had standing to challenge Gladstone's actions, 441 U.S. at 111-15, and further noted that "[a]s we have said before, ' $[t]$ here can be no question about the importance' to a community of 'promoting stable, racially integrated housing.' "Id. at 111 (quoting Linmark Assocs. v. Willingboro, 431 U.S. 85, 94 (1977)). The importance of this observation to the concept of collective rights will be discussed infra in Part III.

238. 412 U.S. 669 (1973).

239. Id. at $672-78$.

240. 40S U.S. 727 (1972); see supra notes 110-16 and accompanying text.

241. "Here, by contrast [with Sierra Club], the appellees claimed that the specific and allegedly illegal action of the Commission would directly harm them in their use of the natural resources of the Washington Metropolitan Area." SCRAP, 412 U.S. at 687.

242. Id. at $687-88$.

243. 418 U.S. 166, 175 (1974); see supra note 127 and accompanying text.

244. 429 U.S. 190 (1976). 
ing widespread injury to constitutional rights: it allowed a third party to assert them. The plaintiffs challenged an Oklahoma statute that prohibited the sale of $3.2 \%$ beer to males but not to females in the same age group, charging that it constituted gender-based discrimination. The case was brought by a male in the restricted age group and by a licensed vendor of beer, but the Supreme Court heard the appeal only from the vendor. ${ }^{245}$ The Court upheld the vendor's standing to sue, noting that she clearly satisfied the injury-in-fact requirement. ${ }^{246}$ The majority recognized, however, that on the merits, the vendor was relying upon an equal protection claim based on unequal treatment of other people. With respect to the nexus problem, the Court stated:

[O]ur decisions have settled that limitations on a litigant's assertion of $j u s$ tertii are not constitutionally mandated, but rather stem from a salutary "rule of self-restraint" designed to minimize unwarranted intervention into controversies where the applicable constitutional questions are illdefined and speculative. . . . These prudential objectives, [generally] thought to be enhanced by restrictions on third-party standing, cannot be furthered here, where the lower court already has entertained the relevant constitutional challenge and the parties have sought-or at least have never resisted-an authoritative constitutional determination. In such circumstances, a decision by us to forgo consideration of the constitutional merits in order to await the initiation of a new challenge to the statute by injured third parties would be impermissibly to foster repetitive and time-consuming litigation under the guise of caution and prudence. Moreover, insofar as the applicable constitutional questions have been and continue to be presented vigorously and "cogently," . . . the denial of $j u s$ tertii standing in deference to a direct class suit can serve no functional purpose. ${ }^{247}$

Craig thus demonstrates the Court's recognition that there may be circumstances where third-party representation of constitutional rights is appropriate, and reaffirms that problems with third-party standing are not constitutionally based. ${ }^{248}$

245. Craig, the young male plaintiff, had exceeded the upper age limit of the affected group following the Court's determination of probable jurisdiction of the appeal, mooting the case as to him. Id. at $192 \&$ n.2.

246. Id. at 194. In fact, the defendants conceded her standing. Id. at 193.

247. Id. at 193-94 (citations omitted).

248. Craig was not a unanimous decision; Chief Justice Burger and Justice Rehnquist dissented. Only the Chief Justice's opinion mentioned the question of the vendor's standing. Justice Rehnquist, who wrote exclusively on the merits, apparently acquiesced in the majority's treatment of the standing issue.

In Carey v. Population Servs. Int'l, 431 U.S. 678 (1977), a strong majority of the Court relied on Craig and allowed vendors of contraceptive devices, on behalf of themselves and potential purchasers, to challenge a New York statute limiting access to and advertisement of contraceptives. Seven members of the Court explicitly joined the portion of the Court's opinion allowing standing. Justice Rehnquist, as in Craig, dissented on the merits without mentioning standing. The Chief Justice dissented without explanation. 
In 1978, the Court clarified some of the limitations of the two-part standing test. In Duke Power Co. v. Carolina Environmental Study Group, Inc., ${ }^{249}$ environmental groups and individuals challenged the Price-Anderson Act's $\mathrm{s}^{250}$ liability limitation for private developers of nuclear power plants. The defendants, the Duke Power Company and the Nuclear Regulatory Commission, argued that the plaintiffs failed to satisfy either prong of the standing test. The Supreme Court disagreed. The Court found the plaintiffs' injury-in-fact in the "environmental and aesthetic consequences of the thermal pollution of the two lakes in the vicinity of the disputed power plants."251 Certainly, the Court said, this is "the type of harmful effect which has been deemed adequate in prior cases to satisfy the 'injury in fact' standard."252 Apart from the plaintiffs' fear of nuclear accidents, therefore, the Court found their allegations of injury sufficiently nonspeculative to justify standing.

The Court flatly repudiated the nexus test's applicability to cases other than taxpayer suits. "We . . . cannot accept the contention that, outside the context of taxpayers' suits, a litigant must demonstrate something more than injury in fact and a substantial likelihood that the judicial relief requested will prevent or redress the claimed injury to satisfy the "case or controversy' requirement of Art. III."253 The Court went on to state explicitly that the other limitations on standing were prudential only, referring specifically to its concerns about the proper role of the courts in American society, ${ }^{254}$ its rejection of the courts as a forum for airing generalized grievances, ${ }^{255}$ and its limited approach to third-party standing. ${ }^{256}$ The Court noted: "Where a party champions his own rights, and where the injury alleged is a concrete and particularized one which will be prevented or redressed by the relief requested, the basic practical and prudential concerns underlying the standing doctrine are generally satisfied when the constitutional requisites are met."257 Thus, the Court seemed almost to merge its prudential concerns into the constitutionally based injury-in-fact requirement, at least for some purposes. To the extent that this occurred, it clearly indicated a liberalization of the

249. 438 U.S. 59 (1978).

250. 42 U.S.C. $\S 2210$ (1982).

251. Duke Power, 438 U.S. at 73.

252. Id. at 73-74 (citing United States v. SCRAP, 412 U.S. 669 (1973); Sierra Club v. Morton, 405 U.S. 727 (1972)).

253. Id. at 79 (footnote omitted).

254. Id. at 80 (citing Warth v. Seldin, 422 U.S. 490 (1975); Schlesinger v. Reservists Comm. to Stop the War, 418 U.S. 208 (1974)).

255. Id. (citing United States v. Richardson, 418 U.S. 166 (1974)).

256. Id. (citing Warth v. Seldin, 422 U.S. 490 (1975); United States v. Raines, 362 U.S. 17 (1960)).

257. Id. at 80-81 (citing Arlington Heights v. Metropolitan Hous. Dev. Corp., 429 U.S. 252 (1977)). 
Court's view on standing. ${ }^{258}$

The Court's approach to standing throughout the past fifteen years has clearly been inconsistent. ${ }^{259}$ The apparently liberal trend of the Court in Camp, SCRAP, Craig, Carey, and Duke Power led to expansions in the concept of injury-in-fact and the availability of third-party standing, as well as a corresponding limitation of the prudentially based nexus test as a restrictive factor in standing. At the same time, in Sierra $C l u b$, the Court took an extremely restrictive approach to the requirements for properly pleading injury-in-fact. Moreover, the Court clearly refused to recognize that any taxpayer or citizen (or, one supposes, all of them ${ }^{260}$ ) might have a sufficient particularized interest in lawful government conduct to give rise to injury-in-fact when government acts unlawfully. ${ }^{261}$ And in Warth v. Seldin, ${ }^{262}$ the Court took an extremely restrictive view of both injury-in-fact and third-party standing, refusing to reach the substantive issues ${ }^{263}$ while insisting on a degree of pleading exactitude and third-party interest not seen prior to that time and certainly inconsistent with its decision a year later in Craig. Finally, in $\mathrm{Val}$ ley Forge, the Court made clear its hostility to citizen claims of unlawful government conduct unless such claimants were able to show some injury more concrete than damage to their interest in having government abide by the social compact. ${ }^{264}$

\section{Problems with the Current Standing Model}

Wholly apart from the inconsistencies in the Court's positions on standing, the majority's increasingly restrictive view of standing poses

258. The Duke Power Court's view of standing was not unanimous. Justice Stewart, concurring in the result, questioned whether the plaintiffs had shown sufficient injury-in-fact to cross the constitutional threshold. Id. at 95 (Stewart, J., concurring).

259. See, e.g., Nichol, supra note 27, and the authorities cited at 68 n.3.

260. See infra Part II, Section $C$.

261. See, e.g., Schlesinger v. Reservists Comm. to Stop the War, 418 U.S. 208 (1974); United States v. Richardson, 418 U.S. 166 (1974); see also supra notes 120.49 and accompanying text.

262. 422 U.S. 490 (1975); see supra notes $159-70$ and accompanying text.

263. Indeed, Justices Douglas and Brennan attributed the Court's decision to something less than dispassionate judicial reasoning. "With all respect, I think that the Court reads the complaint and the record with antagonistic eyes." Warth v. Seldin, 422 U.S. 490, 518 (1975) (Douglas, J., dissenting).

[T] he opinion, which tosses out of court almost every conceivable kind of plaintiff who could be injured by the activity claimed to be unconstitutional, can be explained only by an indefensible hostility to the claim on the merits. I can appreciate the Court's reluctance to adjudicate the complex and difficult legal questions involved . . . . But courts cannot refuse to hear a case on the merits merely because they would prefer not to, and it is quite clear, when the record is viewed with dispassion, that at least three of the groups of plaintiffs have made allegations, and supported them with affdavits and documentary evidence, sufficient to survive a motion to dismiss for lack of standing.

Id. at 520-21 (Brennan, J., dissenting).

264. See Valley Forge Christian College v. Americans United for Separation of Church \& State, Inc., 454 U.S. 464 (1982); supra notes 193-213 and accompanying text. 
substantial problems for a nation that, on the Lockean model, proceeds on the basis that government results from a social compact and is the trustee of the powers settled upon it by the citizens whose consent gives it legitimacy. Many of the problems can be illustrated by extensions of some of the Court's recent standing cases themselves. For example, suppose that Congress passed a joint resolution declaring that the legislative branch could not properly consider the military budget unless each of its members became a general or admiral in the armed forces. Suppose further that the President, as Commander-in-Chief, acceded to the request and commissioned each member. The nation would then be faced with a wholesale, deliberate violation, by Congress and the President, of the incompatability clause. ${ }^{265}$ Yet under the rationale of Schlesinger $v$. Reservists Committee to Stop the War, ${ }^{266}$ no judicial remedy would exist because no one would have standing. Indeed, this hypothetical merely confirms the recognition by the Schlesinger Court that the judicial system provides no remedy for certain types of governmental conduct that violate the Constitution. ${ }^{267}$

Cases like Valley Forge ${ }^{268}$ present similar problems. Assuming that the conveyance to Valley Forge Christian College constituted a prohibited establishment of religion, one may legitimately ask who would have had standing to challenge it. Taxpayer standing was ruled out as a basis, ${ }^{269}$ as was citizen standing, ${ }^{270}$ and the Court explicitly recognized that this created a situation where no conceivable plaintiff could have standing. ${ }^{271}$ Taken to its logical extreme, the reasoning of Valley Forge can, like Schlesinger, lead to utterly absurd results. Suppose Congress conveyed Fort Hood, Texas, to a fundamentalist religious group so that it could establish a center of religious worship. Clearly such a transfer would violate the establishment clause; ${ }^{272}$ yet under the rationale of $\mathrm{Val}$ ley Forge, no one would have standing to seek judicial redress.

In fact, many establishment clause cases raise standing problems under the Valley Forge rationale, problems ordinarily ignored by the

265. U.S. CoNST. art. I, $\S 6$, cl. 2.

266. 418 U.S. 208 (1974); see supra notes $133-49$ and accompanying text.

267. Schlesinger, 418 U.S. at 227.

268. 454 U.S. 464 (1982); see supra notes 193-213 and accompanying text.

269. See supra notes 197-200 and accompanying text.

270. See supra notes 201-02 and accompanying text.

271. See supra text accompanying note 203.

272. U.S. CoNST. amend. I; see, e.g., Committee for Pub. Educ. \& Religious Liberty v. Nyquist, 413 U.S. 756, 779-80 (1973) (invalidating state funding for maintenance and repair of sectarian schools, tuition grants for private school attendance, and tuition tax credits); Tilton v. Richardson, 403 U.S. 672, 682-84 (1971) (upholding federal construction grants to private postsecondary educational institutions only to the extent the funds were used for nonsectarian facilities); Lemon v. Kurtzman, 403 U.S. 602, 625 (1971) (invalidating state salary supplement for teachers in private schools). 
courts deciding such cases. For example, in Zorach v. Clauson, ${ }^{273}$ the plaintiffs challenged a New York program involving released time for public school students to attend religious instruction. The instruction program was not on school premises and received no state financial support, direct or indirect. ${ }^{274}$ The Supreme Court upheld the program without any mention of standing. Yet, viewed in terms of Valley Forge, it is difficult to pinpoint any injury-in-fact to the plaintiffs, whose children remained in the secular schools for instruction during the released time period, other than some injury to their "spiritual stake" in the abstract concept of separation of church and state. ${ }^{275}$ Similarly, in Board of Education v. Allen, ${ }^{276}$ a case challenging a New York program to lend textbooks to religious schools for instruction in secular subjects, the Court also proceeded to the merits without any mention of standing. ${ }^{277}$

Possible cases of government lawlessness in which no one would have standing are not limited either to establishment clause cases or to situations like those in Richardson or Schlesinger. Indeed, the Court's insistence that "generalized grievances" cannot be the basis for standing $^{278}$ raises the spectre of all sorts of abuses by government where no one would have standing to seek judicial intervention. ${ }^{279}$ Clearly, the prospect of a standing doctrine so restrictive as to prohibit the courts from restraining even the grossest types of governmental misconduct is not an enticing one. Yet the Court has warned that recognition of a substantially broader standing doctrine, or one based on an altered concept of injury-in-fact, would eviscerate the constitutional requirements relating to standing. ${ }^{280}$ But the Court's response to the article III prob-

273. 343 U.S. 306 (1952).

274. In this respect, the program differed from the program the Court invalidated in Illinois ex rel. McCollum v. Board of Educ., 333 U.S. 203 (1948).

275. This interest was noted by the Court in dictum in Association of Data Processing Scrv. Orgs. v. Camp, 397 U.S. 150, 154 (1970). See supra note 219 and accompanying text.

276. 392 U.S. 236 (1968).

277. This is not to suggest that the plaintiff will be unable to demonstrate injury-in-fact in any establishment clause case. For example, in McGowan v. Maryland, 366 U.S. 420 (1961), the plaintiff challenged Sunday closing laws. Traditional injury-in-fact was easily demonstrated; enforcement of the laws resulted in plaintiffs loss of revenue from either closing on Sundays or paying fines for being open. Id. at 430-31; see also Larkin v. Grendel's Den, Inc., 459 U.S. 116, 120-27 (1982) (plaintiff had standing to challenge Massachusetts law permitting churches to veto issuance of liquor licenses to establishments within 500 feet).

278. See supra notes 120-41, 201-03 and accompanying text.

279. For example, in the early 1970's, it was rumored that then Vice President Spiro Agnew had discussed suspending the 1972 general elections. See J. DEAN, BLind Ambition 32-33 (1976). Suppose that the Nixon administration had done so, using national security as a pretext to attempt to remain in office. Taking the Court's analysis to its logical extreme, no onc would have standing to challenge the suspension except, perhaps, persons who could make a sufficiently concrcte showing that they would have been candidates in those elections. Everyone else's interest would have been indistinguishable in character from the plaintiff' interest in Valley Forge or Schlesinger.

280. See supra note 202 and accompanying text. 
lem does not follow ineluctably from this premise. In the next Part, this Article proposes a new approach to "stake in the outcome" which leads to a broader, yet still manageable, standing doctrine consistent with our philosophical history.

\section{III}

\section{Collective Constitutional Rights and Their IMPLICATIONS FOR THE DOCTRINE OF STANDING}

The Court's approach to standing. has been inconsistent in two important ways. First, the Justices have not settled on a single concept of injury-in-fact, with reference to how individualized or generalized it must be. ${ }^{281}$ Second, they have inconsistently applied the nexus test, relying heavily upon it in fourth amendment cases $^{282}$ while refusing even to acknowledge it as part of standing doctrine in other than taxpayer suits. ${ }^{283}$ This Part of the Article explores a new approach to standing that eliminates the inconsistencies in current standing doctrine and permits suits involving serious governmental trespasses that currently appear immune from judicial remedy. ${ }^{284}$

This Part first sets out an additional kind of interest in constitutional cases, supplying a new predicate for the constitutionally required "stake in the outcome": ${ }^{285}$ collective rights. Second, the compatibility of a collective stake in the outcome with our Lockean constitutional heritage is demonstrated. Third, areas where collective rights have already been or ought to be recognized are noted and discussed. Finally, this Part proposes a new theory of standing in constitutional cases that is consistent with the foregoing analysis yet does not create universal standing.

\section{A. The Interest To Be Protected and the Lockean Model}

The classic statement of the case-or-controversy requirement in the area of standing is that plaintiffs must have "alleged such a personal stake in the outcome of the controversy as to assure that concrete adverseness which sharpens the presentation of issues upon which the court so largely depends for illumination of difficult constitutional questions." 286 The difficulty, of course, has occurred in applying the concept of "a personal stake in the outcome" to particular fact patterns. The

281. Compare Trafficante v. Metropolitan Life Ins. Co., 409 U.S. 205, 211-12 (1972) with United States v. Richardson, 418 U.S. 166, 176-78 (1974). See also supra notes 128, 227-37 and accompanying text.

282. See supra notes $179-92$ and accompanying text.

283. See Duke Power Co. v. Carolina Envtl. Study Group, Inc., 438 U.S. 59, 78-79 (1978); see also supra notes $249-57$ and accompanying text.

284. See supra pp. 92-94.

285. See Baker v. Carr, 369 U.S. 186, 204 (1962).

286. Id. 
Court insists that if an individual's interest in a controversy is undifferentiated from the rest of the citizenry's, he has not demonstrated a sufficient personal stake in the outcome. ${ }^{287}$ But this doctrinal approach leads to an anomaly: if government broadly and nonspecifically violates the Constitution, no individual has a sufficient stake in the outcome to pursue a judicial remedy. In short, the Court tells us that, for purposes of standing, no one has a sufficient stake to keep government behavior within constitutional limits.

In a Lockean society, this is the ultimate contradiction. The citizenry's compact and consent create the government and give it legitimacy. Citizens' inability to challenge actions that violate the charter of government's existence make the charter unenforceable. ${ }^{288}$ It becomes the constitutional analog of the unenforceable contract that declares, "I will if I want to."289 In fact, however, the Lockean model provides a solution to the dilemma. Because the society creates the government, and because the government is responsible to its creator-not as one contracting party to another but rather as trustee to settlor ${ }^{290}$ or agent to principal ${ }^{291}$ - there is a clear collective societal interest in having the government behave in strict accord with the Constitution. When government violates the Constitution, the stake in the outcome of the controversy is society's stake, and is the most fundamental interest possible: the interest in government functioning as agreed upon by its creators.

The collective interest concept is certainly not new, as Part I demonstrates. Locke conceived of the civil state as one in which government is responsible to society as a whole, rather than to any particular individual. ${ }^{292}$ That concept was echoed in the Declaration of Independence ${ }^{293}$ and subsequent American thought. ${ }^{294}$ Both legal relationships suggested

287. See, e.g., Valley Forge Christian College v. Americans United for Separation of Church \& State, Inc., 454 U.S. 464 (1982); Schlesinger v. Reservists Comm. to Stop the War, 418 U.S. 208 (1974); United States v. Richardson, 418 U.S. 166 (1974); supra notes 120-58, 193-213 and accompanying text.

288. The only possible enforcement mechanism is the electoral process, but that is ill-suited to resolution of constitutional questions. See infra notes 312-21 and accompanying text.

Professor Nichol has noted that the Court's approach to standing in cases like Valley Forge means that the Constitution cannot always be enforced. "The Court . . . views some constitutional provisions as enforceable and others not." Nichol, supra note 27, at 92.

289. In the law of contracts this is referred to as an illusory promise. "Such an illusory promise is neither enforceable against the one making it, nor is it operative as a condition for a return promise." Corbin, The Effect of Options on Consideration, 34 YALE L.J. 571, 574 (1925) (footnote omitted).

290. See supra notes $48-56$ and accompanying text.

291. See supra note 70.

292. See supra notes 58-62 and accompanying text.

293. The Declaration of Independence para. 2 (U.S. 1776).

294. For example, James Madison specifically spoke of "the permanent and aggregate interests of the community," THE FEDERALIST No. 10, at 78 (J. Madison) (C. Rossiter ed. 1961), in arguing 
by the Lockean model of civil society connote collective rights. First, the people whose consent gives rise to government may be regarded as a principal, and government as the agent. ${ }^{295}$ The agency is created by the people acting as a collective unit, not by any individual; hence the responsibility of the governmental agent is to the collective principal. Second, Locke spoke of government as a trustee of powers given to it by the people, ${ }^{296}$ and the people thus become both the settlors and the beneficiaries of the governmental trust. ${ }^{297}$

Two analogies from the law of trusts demonstrate these relationships. The beneficiaries of a trust have standing to challenge the malfeasance of the trustee, though the beneficiary must show that the trustee's conduct has harmed the beneficiary's interest under the trust. ${ }^{298}$ The law of standing in the trust area, therefore, appears to parallel the Supreme Court's injury-in-fact analysis in constitutional adjudication. The Supreme Court has failed to recognize, however, that under the American constitutional model, the beneficiary's interest is the performance of the governmental trustee, not the receipt of more tangible benefits. The settlor of a trust for public benefit also has standing to challenge the misbehavior of his trustee if the settlor retains a beneficial interest in the performance of the trust. ${ }^{299}$ In this respect, Locke's trust metaphor suggests a different concept of standing in constitutional cases, one that recognizes the citizenry as the source of the fiduciary power lodged in government. When a trustee violates the terms of the trust, the settlors and beneficiaries have standing to enforce the terms of the trust through the courts. Why should not the same be true when the governmental trustee violates the terms of the trust expressed in the Constitution?

Of course, one of the terms of this governmental trust is that judicial challenges may be raised only within the limits of the trust agreementthe Constitution. However, the Constitution requires only that a case or controversy exist for the judicial power of the United States to be exercised. It is the Supreme Court that has interpreted the case-or-controversy clause as requiring the individual plaintiff to have a stake in the outcome, ${ }^{300}$ insisted that such a stake can be demonstrated only by plaintiff's injury-in-fact, ${ }^{301}$ and declared that the government's violation of the

for a republican form of government that could "break and control the violence of faction." Id. at 77. Two years later he commented on "the general principle, that laws are unconstitutional, which infringe the rights of the community." 1 ANNALS OF CONG. 458 (J. Gales ed. 1789).

295. See supra note 70 .

296. See supra notes $48-50,57-61$ and accompanying text.

297. See supra note 50 and accompanying text.

298. A. SCOTT, THE LAW OF TRUSTS $\$ \S 199.1-3$ (3d ed. 1967).

299. Id. $\S 200.1$.

300. See, e.g., Baker v. Carr, 369 U.S. 186, 204 (1962).

301. See, e.g., Barlow v. Collins, 397 U.S. 159, 164 (1970); Association of Data Processing Serv. Orgs. v. Camp, 397 U.S. 150, 152 (1970). 
Constitution, without more, can never give rise to the sort of injury that satisfies the case-or-controversy requirement. ${ }^{302}$ The Court's belittling references to "generalized grievances" imply that government's obedience to the Constitution is too meager an interest to deserve judicial attention. In fact, in a society based on the Lockean model, there can hardly be a greater interest, or one more worthy of judicial attention. The question whether the government has complied with the Constitution goes to the civil society's continuing right to exist as an organized unit. ${ }^{303}$

One must remember that society, acting as a unit, creates the government. No individual, standing alone, may properly be regarded as the settlor of the governmental trust. As Locke made clear in discussing society's formation and dissolution, it is the collective body of society that stands in direct relationship to government. For example, recall Locke's description of the two-step process that forms civil society: first, individuals combine into a society, and second, the community vests its power in government as a trust. ${ }^{304}$ Similarly, the right retained by society to dissolve itself and to do away with civil government-the Lockean right of revolution-is also collective. ${ }^{305}$ Thus, the interest in government's proper performance is primarily collective ${ }^{306}$ because of the processes of government formation and dissolution. To the extent the judiciary regulates government on behalf of the people, the scope of adjudication should be affected by the collective model of society upon which the nation is established.

The Supreme Court has not been blind to this sort of collective interest. On occasion, the Court has specifically recognized it. In United States $v$. Richardson, ${ }^{307}$ the Court admitted that its developing standing doctrine might create circumstances in which no one would have standing to sue. It did not, however, regard that as a problem with its doctrine; rather, it viewed that situation as supporting its argument that such controversies should be remitted to the political process for resolution. ${ }^{308}$

[T] hat the Constitution does not afford a judicial remedy does not, of course, completely disable the citizen who is not satisfied with the

302. See, e.g., Valley Forge Christian College v. Americans United for Separation of Church \& State, Inc., 454 U.S. 464, 488-90 (1982); Schlesinger v. Reservists Comm. to Stop the War, 418 U.S. 208, 226-27 (1974).

303. See supra notes $66-70$ and accompanying text.

304. See supra notes 57-58 and accompanying text.

305. See supra notes $66-70$ and accompanying text.

306. That is not to say, of course, that there is no individual interest in proper government functioning. Locke recognized such interests when he described government as existing to protect individuals' property rights, J. LockE, supra note $23, \S 138$, at $378-79$, and the American Bill of Rights was also designed in part to enhance individual interests.

307. 418 U.S. 166 (1974).

308. Id. at 179; see also supra notes 130-31 and accompanying text. 
"ground rules" established by the Congress for reporting expenditures of the Executive Branch. Lack of standing within the narrow confines of Art. III jurisdiction does not impair the right to assert his views in the political forum or at the polls. Slow, cumbersome, and unresponsive though the traditional electoral process may be thought at times, our system provides for changing members of the political branches when dissatisfied citizens convince a sufficient number of their fellow electors that elected representatives are delinquent in performing duties committed to them. ${ }^{309}$

Similarly, in Valley Forge Christian College v. Americans United for Separation of Church and State, Inc., ${ }^{310}$ the Court reiterated that "even when the plaintiff has alleged redressable injury sufficient to meet the requirements of Art. III, the Court has refrained from adjudicating 'abstract questions of wide public significance' which amount to 'generalized grievances,' pervasively shared and most appropriately addressed in the representative branches." 311 Thus, the Court relied upon what it characterized as a "slow, cumbersome, and unresponsive" process for vindication of rights sufficiently significant to merit specific constitutional mention.

There are four shortcomings in the majority's reliance on the political process to correct constitutional violations. First, as the Court itself has recognized, the political process is notoriously slow. Moreover, it is particularly unresponsive to single-issue candidacies, especially at the national level. ${ }^{312}$ The more diverse the electorate and the more complicated the issue facing it, the less any single issue is likely to be dispositive in the electoral process. ${ }^{313}$

Second, the Court in effect makes constitutional decisions a matter

309. Richardson, 418 U.S. at 179. The Court did not explain why its treatment of standing in Richardson compels the conclusion that such disputes should be handled politically.

310. 454 U.S. 464 (1982); see supra notes 193-213 and accompanying text.

311. 454 U.S. at $474-75$ (emphasis added) (quoting Warth v. Seldin, 422 U.S. $490,499-500$ (1975)).

312. See Jaffe, supra note 27 , at $1286-87$ ("Formal majorities register judgments only occasionally, and then as a rule not on specific issues but on total performance."). The phenomenon Professor Jaffe refers to is merely a general reflection of American voting patterns. "The role that any specific issue may play in ultimate partisan choice is limited in several directions. Only rarely does a single policy belief comprise the sole force in the psychological field as the voting decision is made." A. Campbell, P. Converse, W. Miller \& D. Stokes, The American Voter 97-98 (abr. ed. 1964).

313. The Third Circuit has noted the difficulties of the political process in the context of broadening standing: "[U]nless individuals averring an encroachment of their legal rights have some recourse other than the political process for the vindication and protection of those rights, the proud claim that individual citizens have rights against the government may be emptied of significance." Americans United for Separation of Church \& State, Inc. v. Department of Hcalth, Educ. \& Welfare, 619 F.2d 252, 265 (3d Cir. 1980), rev'd sub nom. Valley Forge Christian College v. Americans United for Separation of Church \& State, Inc., 454 U.S. 464 (1982). 
of majority vote. ${ }^{314}$ The Court not only remits certain constitutional questions to the political process for resolution, but it also implicitly declares that the answers are not to be found in the Constitution itself. Rather, they are to be determined by the electoral process-a process against which the Constitution was to provide some insulation. ${ }^{315}$ For example, in Valley Forge, the majority would apparently have the constitutionality of the conveyance be an issue in the next national election, after which, by tallying the vote, one would know whether the conveyance did or did not violate the establishment clause. To the extent that this is the Court's implicit suggestion, it prescribes a form of constitutional relativism that poses substantial difficulties; stare decisis may be less than immutable, but its mood swings certainly cannot compare with those of the American electorate.

The third problem stems from the limitations of the electoral process. Many constitutional questions avoided by the Court on standing grounds cannot be resolved by the electorate, no matter how speedy, consistent, and rational its behavior. For example, in Ex parte Levitt, ${ }^{316}$ the plaintiff argued that Justice Black's appointment to the Supreme Court violated the ineligibility clause. ${ }^{317}$ The political process provided no possible remedy for the allegedly unlawful actions of the President and the Senate that had placed Justice Black on the Court. Federal judges are not subject to recall; they can be removed from office only by impeachment, and then only for conduct not amounting to "good behavior."318 Thus, the allegedly unconstitutional appointment was immune to electoral correction. Similarly, there is no apparent political remedy for the conveyance of federal land to Valley Forge Christian College. Even if the electorate were to unite to vote out of office those responsible for the conveyance, that would provide no mechanism by which to set the con-

314. The Court has previously made a similar suggestion in the fourth amendment context by leaving to the states the question of whether to adopt the exclusionary rule. In Irvine v. California, 347 U.S. 128 (1954), the Court declined to reverse the holding of Wolf v. Colorado, 338 U.S. 25 (1949), overruled by Mapp v. Ohio, 367 U.S. 643 (1961), that the exclusionary rule had no application to the states, though they were bound by the fourth amendment through the 14th amendment. The plurality in Irvine explained that "to upset state convictions even before the states have had adequate opportunity to adopt or reject the rule would be an unwarranted use of federal powcr." 347 U.S. at 134 (Jackson, J.). The Court did not explain why state courts' use of evidence seized in violation of the fourth amendment should become more or less constitutional according to how many states repudiated the practice, nor did it explain how, if the rule were not constitutionally required, the Supreme Court would have any basis for imposing it on the states.

315. Indeed, James Madison noted at some length that the then-proposed Constitution was structured to prevent, to the extent possible, tyrannies of the majority. THE FEDERALIST No. 51 (J. Madison); see also Whitney v. California, 274 U.S. 357, 376 (1927) (Brandeis, J., concurring) (specifically recognizing that the first amendment was intended to limit such tyrannies).

316. 302 U.S. 633 (1937) (per curiam); see supra note 129.

317. U.S. CoNST. art. I, $\S 6, \mathrm{cl} .2$.

318. U.S. CONST. art. III, $\$ 1$. 
veyance aside. ${ }^{319}$ It is, therefore, a bit too facile for the Court to assert, as it did in Richardson, ${ }^{320}$ that questions that the federal courts refuse to address on standing grounds may be resolved through the political process. 321

The fourth problem concerns the role of the federal courts in the constitutional system. Since Marbury $v$. Madison, ${ }^{322}$ the established principle has been that the responsibility for evaluating the constitutionality of congressional and executive actions is lodged in the judiciary. ${ }^{323}$ Even before the Constitution was adopted, James Madison recognized the judiciary's role in restraining government, ${ }^{324}$ and the Supreme Court itself has been unequivocal in its support of this quintessentially judicial function. "[I]t is established practice for this Court to sustain the jurisdiction of federal courts to issue injunctions to protect rights safeguarded by the Constitution and to restrain individual state officers from doing what the 14th Amendment forbids the State to do."325 The Burger Court has recognized that under the Constitution, "the judiciary is clearly discernible as the primary means through which [constitutional] rights may be enforced."326 The Court's assertion, therefore, that the judiciary must yield to the political process when certain constitutional questions arise is in-

319. Indeed, once title became vested in the college, an argument could be made that a subsequent attempt to legislatively undo the conveyance would constitute a taking without just compensation in violation of the fifth amendment.

320. See supra note 309 and accompanying text.

321. That is not to say that no problem presented in a standing case is addressable in the electoral forum. It certainly is true that, upon rejection of his plea in the courts for a declaration that the Central Intelligence Agency Act was unconstitutional, Richardson could have mounted a nationwide campaign to elect a Congress and, if necessary, a President who would effect a repeal of the challenged statute. Some, of course, might view this as impractical. See supra notes 312-13 and accompanying text.

322. 5 U.S. (1 Cranch) 137 (1803).

323. See id.; accord United States v. Nixon, 418 U.S. 683 (I974) (power to review intrabranch dispute between President and special prosecutor); Powell v. McCormack, 395 U.S. 486 (1969) (power to review congressional decision whether to seat a duly elected Member of Congress); Kilbourn v. Thompson, 103 U.S. 168 (1881) (power to review exercise of congressional power to punish uncooperative witnesses).

324. Justice Brennan tried unsuccessfully to bring this part of American history to the Court's attention:

As James Madison noted, if a bill of rights were "incorporated into the Constitution, independent tribunals of justice will consider themselves in a peculiar manner the guardians of those rights; they will be an impenetrable bulwark against every assumption of power in the Legislative or Executive; they will be naturally led to resist every encroachment upon rights expressly stipulated for in the Constitution by the declaration of rights."

Valley Forge Christian College v. Americans United for Separation of Church \& State, Inc., 454 U.S. 464, 494 n.6 (1982) (Brennan, J., dissenting) (quoting 1 ANNALS OF CoNG. 439 (J. Gales ed. 1789)).

325. Bell v. Hood, 327 U.S. 678, 684 (1946) (footnote omitted) (jurisdiction over claim for damages suffered from federal agents' violation of fourth and fifth amendment rights).

326. Davis v. Passman, 442 U.S. 228, 241 (1979) (implied cause of action for due process violation). 
consistent with its own stated view of its role in the constitutional system. $^{327}$

Thus, although the Court recognizes the collective interest in restraining government within the confines of the Constitution, it generally characterizes that interest as insufficient to give rise to a case or controversy within the meaning of article III. ${ }^{328}$ Yet in several areas, the Court has recognized collective rights as part of the constitutional structure, and several Justices frequently speak of rights and remedies in collective terms.

\section{B. The Court's Recognition of Collective Rights}

Explicitly or implicitly, the Supreme Court ${ }^{329}$ has identified collective rights in the first, second, fourth, sixth and thirteenth amendments, ${ }^{330}$ as well as in some of the provisions of article $I^{331}$ In the first amendment area, the collective interest has manifested itself in two ways. First, the Court has clearly demonstrated its recognition of collective interests in public and press access to judicial proceedings. For example, in Richmond Newspapers, Inc. v. Virginia, ${ }^{332}$ the Court specifically noted "a guaranteed right of the public under the First and Fourteenth Amend-

327. Chief Justice Marshall might have viewed the Court's current position more harshly, in light of his assertion in Cohens v. Virginia, 19 U.S. (6 Wheat.) 264 (1821), that for the Court to refuse to exercise power conferred on it by the Constitution is "treason to the Constitution." Id. at 403. And, as Justice (later Chief Justice) Charles Evans Hughes said, "We are under a Constitution, but the Constitution is what the judges say it is . . . D. Perkins, Charles Evans Hughes AND AMERICAN DEMOCRATIC STATESMANSHIP 16 (1956).

328. See, e.g., Schlesinger v. Reservists Comm. to Stop the War, 418 U.S. 208 (1974); United States v. Richardson, 418 U.S. 166 (1974); supra notes 120-53 and accompanying text.

329. One of the most vocal members of the Court in invoking community imagery is Chief Justice Burger, who argues that the community's collective interest must be given greater wcight when balanced against the individual's than has heretofore been the case. But while he adopts the concept of community, the Chief Justice seems to apply it far more to limit assertion of individual constitutional rights than to aid in restricting unlawful governmental actions. See generally Chesler, Imagery of Community, Ideology of Authority: The Moral Reasoning of Chief Justice Burger, 18 HARV. C.R.-C.L. L. REV. 457 (1983).

330. In addition, Justice Marshall made fleeting reference to a "social interest in preserving [fifth amendment] liberties and in the integrity of the criminal justice system" in Jenkins $v$. Anderson, 447 U.S. 231, 254 (1980) (Marshall, J., dissenting), but neither he nor the Court has pursued this idea.

331. Both Schlesinger v. Reservists Comm. to Stop the War, 418 U.S. 208 (1974), and Unitcd States v. Richardson, 418 U.S. 166 (1974), characterized the plaintiff' interests under the ineligibility clause and the accounts clause as no more than generalized grievances, implicitly placing these constitutional provisions in the realm of collective, not individual, interests. A similar argument may be made with respect to Ex parte Levitt, 302 U.S. 633 (1937) (per curiam).

332. 448 U.S. 555 (1980). Richmond Newspapers involved a press challenge to a Virginia trial court order closing a defendant's fourth murder trial to the press at the request of defense counsel. The press' motion to vacate the closure order was denied. The Supreme Court had held a year earlier that there was no public sixth amendment right to attend preliminary court proceedings in criminal cases. Gannett Co. v. DePasquale, 443 U.S. 368 (1979). By contrast, Richmond Newspapers presented the issue whether the first amendment allowed closure of criminal trials. The 
ments to attend the trial."333 Justice Brennan, concurring in the judgment, explored the nature of the public right at greater length and argued for more explicit recognition under the first amendment of such a public right to receive information. ${ }^{334}$ In these respects, Richmond Newspapers echoed dicta from earlier cases that suggested recognition of a public constitutional right. ${ }^{335}$ Thus, the Court has clearly recognized an interest held by the public under the first amendment to attend criminal trials. ${ }^{336}$

Individual Justices have also argued on the basis of collective first amendment rights. For example, Justice Black, joined by Chief Justice Warren and Justice Douglas, dissented in Barenblatt $v$. United States, ${ }^{337}$ a decision that affirmed a contempt of Congress conviction entered against a teacher who refused to answer questions of the House UnAmerican Activities Committee. Justice Black specifically referred to "the interest of the people in having [first amendment rights] exercised."338 Later in the same opinion, he sharply criticized the majority's approach:

[The Court] balances the right of the Government to preserve itself, against Barenblatt's right to refrain from revealing Communist affiliations. Such a balance, however, mistakes the factors to be weighed . . . [and] completely leaves out the real interest in Barenblatt's silence, the interest of the people as a whole in being able to join organizations, advocate causes and make political "mistakes" without later being subjected to governmental penalties for having dared to think for themselves. . . . It is these interests of society, rather than Barenblatt's own right to si-

Court declined to extend Gannett, but explicitly based its holding on the first, rather than the sixth amendment.

One remarkable aspect of Richmond Newspapers is its unarticulated assumption of the petitioner's standing where the interest invoked was no less undifferentiated from that of the general citizenry than that in Valley Forge. See infra notes 388-92, 396-97 and accompanying text.

333. Richmond Newspapers, 448 U.S. at 580 . Though the Chief Justice's opinion was only for a plurality of the Court, this aspect of it was joined by Justices Brennan, Stewart, White, Marshall, Blackmun and Stevens. Accord Globe Newspaper Co. v. Superior Court, 457 U.S. 596, 603 (1982) ("Richmond Newspapers firmly established . . . that the press and general public have a constitutional right of access to criminal trials. . . . [S] even Justices recognized that this right of access is embodied in the First Amendment, and applied to the States through the Fourteenth Amendment."); see also United States v. Chagra, 701 F.2d 354 (5th Cir. 1983) (access to pretrial criminal proceedings, specifically bail reduction hearing); United States v. Criden, 675 F.2d 550 (3d Cir. 1982) (access to pretrial suppression, due process, and entrapment hearings).

334. Richmond Newspapers, 448 U.S. at 585-98 (Brennan, J., concurring in judgment); see also id. at 598-601 (Stewart, J., concurring in judgment).

335. E.g., Estes v. Texas, 381 U.S. 532, 541 (1965) ("[T]he public has the right to be informed as to what occurs in its courts . . . ."); Craig v. Harney, 331 U.S. 367, 374 (1947) ("A trial is a public event. What transpires in the court room is public property.").

336. The Third Circuit recently recognized that the public and press have a first amendment right of access to civil proceedings as well. Publicker Indus. v. Cohen, 733 F.2d 1059 (3d Cir. 1984).

337. 360 U.S. 109 (1959).

338. Id. at 143 (Black, J., dissenting). 
lence, which I think the Court should put on the balance against the demands of the Government, if any balancing process is to be tolerated. ${ }^{339}$

Thus, the three Justices recognized both the existence of a cognizable collective interest in the first amendment and the importance of considering the possible antagonism between the collective, societal interest and the government's interest. The collective interest not only exists as a constitutional concept, but also requires protection from the government itself; the government cannot be assumed to represent it. ${ }^{340}$

The Court's recognition of collective rights in the first amendment area has not been limited to questions of public access to courts. In Scripps-Howard Radio, Inc. v. FCC ${ }^{341}$ and FCC v. Sanders Brothers Radio Station, ${ }^{342}$ which concerned disputes over FCC licenses to operate radio stations, the Court expressly recognized the status of radio stations as representatives of the public interest. In Scripps-Howard, the petitioner contested a modification of a competitor's license. In reviewing the petitioner's standing, the Court noted that the Communications Act of $1934^{343}$ was designed to protect "the public interest in communications." 344 The Act conferred a right of appeal on aggrieved persons, but the Court noted the limitations of that right. "[T] hese private litigants have standing only as representatives of the public interest. . . . That a court is called upon to enforce public rights and not the interests of private property does not diminish its power to protect such rights."345 Thus, the Court recognized that Congress had created a statutory collective right in this area because of communication's public importance.

Regarding the second amendment, courts have been even clearer about the nature of the right guaranteed. Case after case has considered whether the right to bear arms is an individual or a collective right. The Sixth Circuit, for example, stated unequivocally that "[i]t is clear that the Second Amendment guarantees a collective rather than an individual right,"346 a view apparently reflected by every court to have considered

339. Id. at 144 (Black, J., dissenting).

340. See also Bursey v. United States, 466 F.2d 1059, 1083 (9th Cir. 1972) (public interests in the first amendment may be more important than personal interests).

341. 316 U.S. 4 (1942).

342. 309 U.S. 470 (1940).

343. 47 U.S.C. $\$ \S \mathrm{i} 51-610$ (1982).

344. Scripps-Howard, 316 U.S. at 14.

345. Id. at 14-15 (citing FCC v. Sanders Bros. Radio Station, 309 U.S. 470, 477 (1940); National Licorice Co. v. NLRB, 309 U.S. 350 (1940)). The Court's remarkable position that the petitioner had standing not as a private entity but only as a public representative stands in stark contrast to the Court's more common assertion that to represent the public interest a litigant must demonstrate a private right. See, e.g., Sierra Club v. Morton, 405 U.S. 727 (1972); see supra notes 114-16 and accompanying text. This apparently lenient position might be thought to result in part from the holding's statutory, rather than constitutional, basis. But see infra note 365 .

346. United States v. Warin, S30 F.2d 103, 106 (6th Cir.), cert. denied, 426 U.S. 948 (1976). 
the issue specifically. ${ }^{347}$ The courts have adopted this position because of the introductory phrase of the second amendment, referring to the right to bear arms in the context of maintenance of a militia. ${ }^{348}$ Nonetheless, it is significant that the courts have explicitly recognized that the Framers of the Constitution intended to create at least one collective right. It is also noteworthy that this recognition came in consideration of an amendment that speaks of rights held by a plural entity, the people, rather than by an individual. Compare the rights of "the people" referred to in the first, second, fourth, ninth, and tenth amendments with those of "the person" and "the accused" safeguarded in the fifth and sixth amendments. The second amendment joins the first as a provision in which collective rights have received a judicial imprimatur.

In the fourth amendment area, the Supreme Court has been less forthright about recognizing collective interests, but it has nevertheless done so in cases considering application of the exclusionary rule. Through the 1970's, the Court emphasized that the exclusionary rule exists to protect the collective, societal interest in deterring fourth amendment violations, and not to make whole the victim of an unlawful search or seizure. ${ }^{349}$ Moreover, the Court used that societal interest concept as a predicate for refusing to apply the exclusionary rule in cases where the individual would have benefited by its application but the deterrent effect-the benefit to society generally-would have been more tenuous. ${ }^{350}$ The collective interest is, therefore, now clearly recognized in the fourth amendment area, though in the cases where the Court has commented

347. E.g., United States v. Johnson, 497 F.2d 548 (4th Cir. 1974); United States v. Tot, 131 F.2d 261 (3d Cir. 1942), rev'd on other grounds, 319 U.S. 463 (1943); Burton v. Sills, 53 N.J. 86, 248 A.2d 521 (1968), appeal dismissed, 394 U.S. 812 (1969); see also United States v. Miller, 307 U.S. 174 (1939). But see Levine \& Saxe, The Second Amendment: The Right To Bear Arms, 7 Hous. L. REV. 1 (1969) (suggesting that the second amendment guarantee is individual as well as collective).

348. "A well regulated Militia, being necessary to the security of a free State, the right of the people to keep and bear Arms, shall not be infringed." U.S. CONST. amend. II.

349. See, e.g., United States v. Calandra, 414 U.S. 338 (1974):

The purpose of the exclusionary rule is not to redress the injury to the privacy of the search victim: "[T]he ruptured privacy of the victims' homes and effects cannot be restored. Reparation comes too late." Instead, the rule's prime purpose is to deter future unlawful police conduct and thereby effectuate the guarantee of the Fourth Amendment against unreasonable searches and seizures. . . . In sum, the rule is a judicially created remedy designed to safeguard Fourth Amendment rights generally through its deterrent effect, rather than a personal constitutional right of the party aggrieved.

Id. at 347-48 (quoting Linkletter v. Walker, 381 U.S. 618, 637 (1965)); accord United States v. Janis, 428 U.S. 433, 453-54 (1976); United States v. Turk, 526 F.2d 654 (5th Cir.), cert. denied, 429 U.S. 823 (1976).

A contrary suggestion appears in Harrison v. United States, 392 U.S. 219 (1968), which mentions that one of the exclusionary rule's benefits is that it "restores the situation that would have prevailed if the Government had itself obeyed the law." Id. at 224 n.10. Harrison has not been followed.

350. See, e.g., United States v. Janis, 428 U.S. 433 (1976); United States v. Calandra, 414 U.S. $338,349-52$ (1974). 
upon the societal interest, it has used that interest as a reason for refusing to punish unconstitutional government behavior. Despite that unusual twist, this development of fourth amendment jurisprudence is important because of the emergence of the collective interest analysis. ${ }^{351}$

The collective, public interest in the fourth amendment was specifically mentioned in Justice Harlan's dissent in United States v. White. ${ }^{352}$

[T] $\mathrm{T}$ issue here is whether to interpose a search warrant procedure bctween law enforcement agencies engaging in electronic eavesdropping and the public generally. By casting its "risk analysis" solely in terms of the expectations and risks that "wrongdoers" or "one contemplating illegal activities" ought to bear, the plurality opinion, I think, misses the mark entirely. [By not requiring warrants to eavesdrop, the Court] does not simply mandate that criminals must daily run the risk of unknown eavesdroppers prying into their private affairs; it subjects each and every law-abiding member of society to that risk. ${ }^{353}$

It was the public interest that Justice Harlan felt had been given insufficient consideration by the White plurality. But because White was written in Justice Harlan's last year on the bench, it is impossible to tell whether his collective-interest interpretation would have swayed other members of the Court in the 1970's standing cases had he been there to urge it. ${ }^{354}$

The Court has also implicitly recognized a public interest in the sixth amendment guarantee of a jury trial in all criminal cases. ${ }^{355}$ Some defendants, however, prefer to be tried to the court. The Federal Rules of Criminal Procedure permit a defendant to waive a jury and be tried to the court, provided the judge and prosecutor agree. ${ }^{356}$ In Singer $v$. United States, ${ }^{357}$ the Supreme Court upheld this restriction on the waiver of a jury trial. The Singer Court did not discuss why the waiver limita-

351. For a detailed argument in favor of recognition of a collective fourth amendment right, see Doernberg, supra note 29.

352. 401 U.S. 745 (1971). Justice Harlan opposed reaffirmation of the Court's rule permitting warrantless electronic eavesdropping with the consent of any party to a conversation. That rule had been adopted by the Court in On Lee v. United States, 343 U.S. 747 (1952). The Court had occasion in White to reconsider On Lee because the Seventh Circuit had reversed White's narcotics conviction on the ground that On Lee had been overruled by Katz v. United States, 389 U.S. 347 (1967). Katz had ruled that wiretapping or eavesdropping could constitute a fourth amendment violation despite the absence of physical trespass into an area in which the search victim had a reasonable expectation of privacy. In White, the Court declined to extend Katz to the situation where one of the parties to a conversation has consented to the electronic intrnsion.

353. White, 401 U.S. at 789 (Harlan, J., dissenting).

354. See supra text accompanying notes 179-92.

355. The Supreme Court now reads the word "all" in the sixth amendment to mean "some," permitting a nonjury trial over the defendant's objection where the offense charged is "petty": i.c. carries a possible penalty of less than six months imprisonment. See Baldwin v. New York, 399 U.S. 66, 69 (1970); Duncan v. Louisiana, 391 U.S. I45, 159 (1968).

356. FED. R. CRIM. P. 23(a).

357. 380 U.S. 24 (1965). 
tion had been instituted, but at least one reason may be inferred from the opinion. The Court noted that " $[t]$ rial by jury has been established by the Constitution as the 'normal and . . . preferable mode of disposing of issues of fact in criminal cases.' "358 But to whom is this mode of adjudication preferable? The preference is obviously not the defendant's, since Singer sought to waive the jury trial. The Singer Court's statement must reflect, therefore, the existence of an unarticulated public interest in the sixth amendment right to jury trial. ${ }^{359}$

The thirteenth amendment ${ }^{360}$ also indirectly implicates collective rights. Titles VIII and IX of the Civil Rights Act of 1968, ${ }^{361}$ which concern fair housing practices, were enacted as enforcement measures in order to eliminate one of the remaining badges of slavery in American society. ${ }^{362}$ In both Gladstone, Realtors v. Village of Bellwood ${ }^{363}$ and Trafficante v. Metropolitan Life Insurance Co., ${ }^{364}$ the Supreme Court explicitly noted the community interest embodied in the Act and seized upon congressional recognition of that interest as a reason to find standing for plaintiffs against whom there had been no discriminatory action. Such plaintiff' interest in integrated community living surely was undifferentiated from anyone else's similar interest; yet the Court, affirming the community interest, found standing. ${ }^{365}$ This is significant for two reasons. First, it acknowledges another judicially cognizable collective right-a thirteenth amendment right to reside in a community the composition of which is not determined by race. Second, it casts grave doubt on the Court's repeated assertions ${ }^{366}$ that generalized grievances-those shared by the community at large-cannot meet the requirements of the case-or-controversy provision. If that were so, congressional recognition of such interests would do nothing to alter or satisfy the constitutional minima. Gladstone and Trafficante are the Court's implicit recognition

358. Id. at 35 (quoting Patton v. United States, 281 U.S. 276, 312 (1930)).

359. The rule might be seen merely as an attempt to ensure that defendants' waivers of this constitutional right are knowing and intelligent within the meaning of Johnson v. Zerbst, 304 U.S. 458 (1938). But such paternalism would be anomalous given that other constitutional rights under the fourth, fifth, and sixth amendments may be waived unilaterally.

360. U.S. CONST, amend. XIII, $\S 1$ : "Neither slavery nor involuntary servitude, except as a punishment for crime whereof the party shall have been duly convicted, shall exist within the United States, or any place subject to their jurisdiction."

361. 42 U.S.C. $\$ \S 3601-3619,3631$ (1982).

362. Williams v. Matthews Co., 499 F.2d 819, 825 (8th Cir.), cert. denied, 419 U.S. 1021 (1974); United States v. Hunter, 459 F.2d 205, 214 (4th Cir.), cert. denied, 409 U.S. 934 (1972).

363. 441 U.S. 91 (1979).

364. 409 U.S. 205 (1972); see supra notes 227-37 and accompanying text.

365. The fact that a statute explicitly provided standing is unimportant. If undifferentiability of the plaintiffs injury from the injury suffered by the public generally meant that no case or controversy existed, as the Court suggested in Schlesinger and Richardson, then the congressional attempt to grant standing through the statute would be ineffective. It is the nature of the interest asserted vis-a-vis the Constitution that is important, not the source from which the interest springs.

366. See supra notes 137-41, 201-03 and accompanying text. 
that the community can have a stake in the outcome sufficient to have its interest represented by one of its members without running afoul of article III.

There are, in addition, two procedural analogs to the substantive collective rights that the courts have recognized. Generalized interests have been vindicated in the courts by representatives from the private and public sectors. When such representation is by a private individual, the courts refer to him as a private attorney general. When the public sector is involved in the representation, the concept of parens patriae is employed.

Private attorneys general have been explicitly recognized in a variety of contexts. For example, in Newman v. Piggie Park Enterprises, ${ }^{367}$ the Court specifically approved of individuals acting as private attorneys general to enforce provisions of the Civil Rights Act of 1964.368 The private attorney general theory was also used in Trafficante $v$. Metropolitan Life Insurance Co., ${ }^{369}$ with respect to the Civil Rights Act of 1968, ${ }^{370}$ and it has been used to enforce the 1965 Voting Rights $\mathrm{Act}^{371}$ and the Social Security Act. ${ }^{372}$ It appears, however, that plaintiffs have never been accorded standing as private attorneys general in constitutional cases. ${ }^{373}$ Nonetheless, the concept of collective interest clearly inheres in the concept of private attorneys general, and it would be difficult to argue that policies more important than those contained in the Constitution exist.

Parens patriae involves state action on behalf of its citizens pursuant to its duty to safeguard the general welfare of the people. The Supreme Court has accepted the principle of parens patriae suits. ${ }^{374}$ In Georgia $v$. Pennsylvania Railroad, ${ }^{375}$ the Court permitted the state to bring a parens

367. 390 U.S. 400 (1968) (per curiam).

368. 42 U.S.C. $\S \S 2000$ a to a-6 (1982) (as amended).

369. 409 U.S. 205 (1972); see supra notes $227-37$ and accompanying text.

370. 42 U.S.C. $\S \S 3601-3619,3631$ (1982) (as amended).

371. Id. $\S \S 1971,1973$ to $1973 \mathrm{~b}-4$ (as amended); see Allen v. State Bd. of Elections, 393 U.S. 544 (1969).

372. 42 U.S.C.A. $\S \S 301-1397 f$ (West 1983); see National Welfare Rights Org. v. Finch, 429 F.2d 725 (D.C. Cir. 1970).

373. In United States Parole Comm'n v. Geraghty, 445 U.S. 388 (1980), the Court analogized the right of class certification to the concept of the private attorney general in cases where the class representative's individual claim became moot or was otherwise resolved. Id. at 403. This analogy was dictum, however, as the Court ruled that appellate courts may review denial of a class certification motion even though the proposed representative's claim has become moot. The representative has standing to appeal because he has a "personal stake" in obtaining class certification within the traditional meaning of that language.

374. Hawaii v. Standard Oil Co., 405 U.S. 251, 258 (1972) (citing New York v. New Jersey, 256 U.S. 296 (1921); Kansas v. Colorado, 206 U.S. 46 (1907); Missouri v. Illinois, 180 U.S. 208 (1901); Louisiana v. Texas, 176 U.S. 1 (1900)).

375. 324 U.S. 439 (1945). 
patriae suit to obtain injunctive relief against railroads allegedly violating the antitrust laws. And, in Hawaii v. Standard Oil Co. ${ }^{376}$ the Court reaffirmed the parens patriae principle, though it refused to permit the state as parens patriae to seek damages on behalf of its citizens.

But here too, the Court has explicitly denied states the use of parens patriae suits to challenge federal government actions on constitutional grounds. In Massachusetts v. Mellon, ${ }^{377}$ the Court stated:

It cannot be conceded that a State, as parens patriae, may institute judicial proceedings to protect citizens of the United States from the operation of the statutes thereof. While the State, under some circumstances, may sue in that capacity for the protection of its citizens . . . it is no part of its duty or power to enforce their rights in respect of their relations with the Federal Government. In that field it is the United States, and not the State, which represents them as parens patriae, when such representation becomes appropriate. . . . 378

One must remember, though, that Massachusetts $v$. Mellon and the cases that followed it were decided by a Court that had not focused its attention on the concept of collective rights under the Constitution and the implications of their existence. Moreover, Mellon itself seemed not to question the existence of collective interests so much as it disputed whether the state was the appropriate representative to enforce them in this particular case. ${ }^{379}$ What is significant is that the parens patriae doctrine represents an additional judicial recognition of circumstances in which collectively held rights may be vindicated by a litigant who cannot show the type of individualized injury normally required by the Court to confer standing.

The courts, therefore, have frequently given express or implied recognition to collectively held rights under the Constitution. Indeed, the idea of collective rights is not only consistent with the United States' constitutional and philosophical heritage, it is virtually compelled by it. What the courts have never done, however, is to synthesize these concepts with the doctrine of standing so that the doctrine permits protection of such rights rather than functioning as a barrier to their assertion and vitality. It is therefore necessary to develop a new theory of standing that permits representation of collective rights without simultaneously threatening to inundate the courts with suits that are frivolous, duplicative or both. The next Section addresses this problem.

376. 405 U.S. 251 (1972).

377. 262 U.S. 447 (1923).

378. Id. at 485-86 (citation omitted); see also Oklahoma v. Atchison, T. \& S.F. Ry., 220 U.S. 277 (1911) (parens patriae concept will not support original Supreme Court jurisdiction when the state in fact seeks to represent citizens' interests but not its own). See generally Note, Standing of States to Represent the Interests of Their Citizens in Federal Court, 21 AM. U.L. REv. 224 (1971). 379. See Mellon, 262 U.S. at 485. 


\section{Standing to Vindicate Collective Rights}

As the law of standing exists today, collective interests in constitutional provisions cannot be effectively protected. Collective rights are vindicated from time to time when they fortuitously appear in cases in which a litigant can demonstrate individual standing, but there is no systematic way for these rights to receive their due. The difficulty with current standing theory lies in its restrictive view of the case-or-controversy requirement. It is the Court, not the Constitution, that has defined a case in terms of the plaintiff's stake in the outcome and further defined that stake in terms of personal injury-in-fact. But as the Court itself has recognized, there exists a collective interest in government behavior constrained by constitutional limits-an interest the Court disparagingly refers to as "generalized grievances." 380 What the Court fails to realize is that, in any society founded on the Lockean model, the citizens have an enormous collective stake in the governmental trustee acting within its powers and limitations. ${ }^{381}$ When government violates the Constitution, society's interest is implicated, and that interest should be addressable in the courts. ${ }^{382}$

Who is to represent the societal interest? Possible cases may be divided into two groups based on the constitutional provisions and governmental actions involved. In the first group, government actions violating the Constitution necessarily produce an injury-in-fact traceable to a specific individual. For example, government suppression of speech in violation of the first amendment produces two types of injury. One is collective; society's rights both to hear what the speaker would have said $^{383}$ and to have government act according to the Constitution suffer when government becomes censor. The second injury is to the would-be speaker; his constitutional right to speak is impaired. This case presents a situation where judicial vindication of an individual's rights and redress of his injury a fortiori protects the public right simultaneously. ${ }^{384}$ Similarly, when the government conducts a search without probable cause or

380. See supra notes $137-41,201-03$ and accompanying text.

381. See supra notes $286-91$ and accompanying text.

382. See supra notes $322-27$ and accompanying text. In American society, three methods are available to address government's constitutional violations: through the political process, through the courts, and through exercise of the Lockean right of revolution. For most purposes, the first is both impractical and inappropriate, see supra notes 312-21 and accompanying text, and the last is impractical and undesirable. Locke himself made clear that the right of revolution is to be exercised only in cases of the grossest government malfeasance. See supra notes $66-70$ and accompanying text. The true alternatives, therefore, are acquiescence in constitutional violations or resort to the courts. 383. See supra notes $332-45$ and accompanying text.

384. By contrast, if the individual chooses to acquiesce in the violation of his constitutional right to speak, current standing doctrine leaves no one to protect the collective interest since the right to receive information has not been accorded explicit first amendment status by the Court. See, c.g., Richmond Newspapers, Inc. v. Virginia, 448 U.S. 555, 584-89 (1980) (Brennan, J., concurring). 
a warrant in violation of the fourth amendment, the criminal defendant's subsequent motion to suppress the fruits of the search also serves to invoke the judicial power to protect the collective privacy interest embodied in the fourth amendment. ${ }^{385}$ In a series of cases, ${ }^{386}$ however, the Court has ruled that though the government might have violated the fourth amendment and though the defendant might have been directly injured thereby, he is without standing to complain of the government's illegal conduct. In such circumstances, the collective right cannot be vindicated under current standing doctrine, despite the presence of an individual injured in fact as a direct result of the constitutional violation. The difficulty arises because the Court has silently substituted the legallyprotected-interest test for the injury-in-fact test of standing. ${ }^{387}$ It has created a subgroup of cases where collective rights could be vindicated by individuals injured in fact, but where such individuals are refused standing either to represent the collective interest or to seek redress of the injury-in-fact they have suffered as individuals.

In the second group of cases, a governmental constitutional violation cannot produce individualized injury-in-fact as that term has been interpreted by the Court. Valley Forge Christian College v. Americans United for Separation of Church and State, Inc. ${ }^{388}$ Schlesinger $v$. Reservists Committee to Stop the War, ${ }^{389}$ United States v. Richardson, ${ }^{390}$ and Ex parte Levitt ${ }^{391}$ are examples of cases in this group. In these cases, it was impossible for the plaintiffs to demonstrate any injury-in-fact attributable to them individually; yet, if their allegations could have been proved, the government would have been guilty of violating the Constitution. Nonetheless, in Valley Forge, Schlesinger, and Richardson, the Court recognized the possibility that no conceivable plaintiff would have standing. ${ }^{392}$

The two groups of cases suggest different tests for standing. Where the government's unconstitutional act can give rise to individualized injury-in-fact, it seems appropriate to insist that the one who challenges the action be one of those injured. But at the same time, the test of injury should remain faithful to the injury-in-fact standard that the Court has developed and should not retreat to the legally-protected-interest test unanimously repudiated by the Court. ${ }^{393}$ Thus, in the fourth amend-

\footnotetext{
385. See supra notes $349-54$ and accompanying text.

386. See supra notes $179-92$ and accompanying text.

387. See supra notes $190-92$ and accompanying text.

388. 454 U.S. 464 (1982); see supra notes 193-203 and accompanying text.

389. 418 U.S. 208 (1974); see supra notes 133-42 and accompanying text.

390. 418 U.S. 166 (1974); see supra notes $128-30$ and accompanying text.

391. 302 U.S. 633 (1937) (per curiam); see supra note 129.

392. See supra note 203 and accompanying text.

393. See Barlow v. Collins, 397 U.S. 159 (1970); Association of Data Processing Serv. Orgs., Inc. v. Camp, 397 U.S. 150 (1970); supra notes 214-26 and accompanying text.
} 
ment context, the use of illegally seized evidence would constitute injuryin-fact to the defendant. He would therefore qualify as a representative of society's interest in privacy reflected in the fourth amendment. Similarly, a member of the public or a reporter who is excluded from the courtroom is injured in fact and is the appropriate person to represent the public's first amendment interest in open judicial proceedings. The Supreme Court has recognized this sort of vicarious representation of the public interest claimed by plaintiffs. As the court said in Sierra Clubv. Morton, ${ }^{394}$ once a plaintiff has standing, he may argue the public interest in support of his claim that the government has exceeded its lawful authority. ${ }^{395}$

The second group of cases, where the unconstitutional government action cannot result in injury-in-fact to an individual, poses a more difficult problem for standing purposes. The Court has declared that such cases present "generalized grievances." Plaintiffs fail to present an article III case or controversy in these cases because their stake in the outcome is indistinguishable from that of anyone else. ${ }^{396}$ The result is that the collective right involved is left unprotected and unenforceable. Therefore, I propose that individuals be accorded standing, much as private attorneys general, ${ }^{397}$ to present constitutional challenges to unlawful government action on behalf of the collective public interest. There can be no question that the citizenry has a stake in the outcome of a constitutional case where the issue is whether the government has violated its charter. The conflict between the collective interest in constitutionalism on one hand and government's unlawful behavior on the other should be found to meet the case-or-controversy requirement of Article III. There is, accordingly, no constitutional impediment to the concept of citizen standing in the kind of case described here, provided that one does not view all possible interests atomistically, each having no possible connection to the others.

Citizen standing as proposed here would, however, present two potential problems. First, if unregulated, it might open the doors of the federal courthouses to a flood of constitutional litigation from persons who would lack standing under current doctrine. Second, it raises the possibility that the citizens who undertake to represent the public interest may not be fit to do so. Both difficulties can be overcome through the use

394. 405 U.S. 727 (1972).

395. Id. at 737 (footnote omitted) (citing Scripps-Howard Radio, Inc. v. FCC, 316 U.S. 4 (1942); FCC v. Sanders Bros. Radio Station, 309 U.S. 470 (1940)).

39.6. See, e.g., Valley Forge Christian College v. Americans United for Separation of Churclı \& State, Inc., 454 U.S. 464 (1982); Schlesinger v. Reservists Comm. to Stop the War, 418 U.S. 208 (1974); United States v. Richardson, 418 U.S. 166 (1974).

397. See supra notes $367-73$ and accompanying text. 
of a single device in citizen standing cases: the class action. ${ }^{398}$ Courts have always determined the appropriateness of prospective class representatives in class actions. The Federal Rules of Civil Procedure require both that the representative party assert a claim typical of the class ${ }^{399}$ and that he "fairly and adequately protect the interests of the class."

398. The standing proposal advanced here requires no modification of the class action device itself. Once the existence of judicially cognizable collective interests is recognized, established class action principles permit appropriate invocation of the judicial power to protect such interests.

399. FED. R. CIV. P. 23(a)(3). The claims of named plaintiffs are typical of the class' claims when they are based on the same legal and remedial theories and when there is no adversity between the named plaintiffs and unnamed class members. 7 C. WRIGHT \& A. Miller, Federal Practice AND Procedure $§ 1764$ (1972); see also Mersay v. First Republic Corp. of America, 43 F.R.D. 465, 468-69 (S.D.N.Y. 1968). Clearly, when a single governmental act or pattern of acts is challenged as unconstitutional, a citizen's claim will be typical; the constitutional theories asserted will be common to all. It is possible, of course, that the class representative may not raise all of the possible constitutional objections to the challenged government activity. The failure of the representative and his counsel to raise and vigorously to pursue all nonfrivolous constitutional arguments goes directly to the representative's fitness to represent the class. See infra note 400 . If the court feels that the named class representative overlooks or rejects appropriate arguments, certification of the class should be refused or, if already granted, should be withdrawn pursuant to FED. R. CIV. P. 23(c)(1). "The district court may decertify a class after trial if plaintiff's trial performance showed him or her to be an inadequate class representative." Payne v. Travenol Laboratories, Inc. 673 F.2d 798, 811 (5th Cir. 1982) (citing Johnson v. Uncle Ben's Inc., 628 F.2d 419 (5th Cir. 1980)), vacated and remanded on other grounds, 451 U.S. 902 (1981). It has been argued that the district court has an affirmative duty to decertify a class where the representative is unsuitable. Sessum v. Houston Community College, 94 F.R.D. 316, 322 (S.D. Tex. 1982) (citing DeGrace v. Rumsfeld, 614 F.2d 796 (1st Cir. 1980)). But see Carpenter v. Steven F. Austin State Univ., 706 F.2d 608, 617-18 (5th Cir. I983) (suggesting that after trial, a new class representative should be appointed in preference to decertifying the class).

There is also no possibility of judicially cognizable adversity among the class members. It is, of course, conceivable that some members of the citizen class might not wish the government to correct its allegedly unconstitutional behavior. For example, supporters of Valley Forge Christian College might applaud the land grant even if it violated the first amendment. This would not make plaintiffs' claims any less representative of the claims of the class. "Whether all the members desire to exercise these rights is not relevant to the issues in the litigation. The possibility that some might not, at this time, wish to exercise their right . . . does not preclude a class action." Cortright v. Resor, $325 \mathrm{~F}$. Supp. 797, 808 (E.D.N.Y.), rev'd on other grounds, 447 F.2d 245 (2d Cir. 1971), cert. denied, 405 U.S. 965 (1972). Moreover, one would hesitate to assert that there is a judicially cognizable interest in having government continue to violate the Constitution. Accordingly, though as a practical matter there may not be unanimity among members of the citizen class with respect to any particular action, its absence does not undermine the propriety of the device.

Similarly, class members may have divergent views on whether the government's action is constitutional, wholly apart from their feelings on its desirability. Such a difference of opinion does not, in this sort of public action any more than in any class action, constitute adversity among members of the class. It is the function of the courts, not the class members, to decide the constitutional issue. Indeed, to allow differences of opinion among class members to defeat the representativeness of the named plaintiff would make it impossible for anyone to raise the constitutional challenge at all. Thus, to allow diversity of opinion to preclude a public class action of the type advocated in this Article would be to recognize a theory of constitutional relativism similar to that discussed supra in notes 314-15 and accompanying text. In this case, however, diversity of public opinion would be the cause of the judiciary's decision not to resolve the controversy rather than a result of judicial abstention.

400. FED. R. CIV. P. 23(a)(4). Courts generally focus on two factual questions in determining whether the named plaintiffs will fairly and adequately protect the interest of absent class members: 
The federal courts certainly have not been reluctant to refuse to certify classes where the representative or counsel has been found to be inadequate. ${ }^{401}$ When the plaintiff asserts citizen standing, and therefore purports to represent the public interest, this inquiry will be crucial.

The threat of multiple actions dealing with identical constitutional issues can also be met by the class action device. The federal courts should establish a nationwide central indexing system to catalog ongoing class actions invoking the collective-right, citizen-standing principles discussed here. Once a citizen class is certified, ${ }^{402}$ all other district courts should refuse to entertain similar suits since the plaintiffs before them would already be parties in another case presenting the same question. Duplicative actions can be stayed, enjoined, or dismissed. ${ }^{403}$ In this manner, only one citizen-standing challenge to a particular governmental action could be maintained. It is precisely this sort of economy of judicial and litigative effort that the class action was in part designed to achieve. ${ }^{404}$ Appropriate use of the class action device, therefore, suggests a solution to the two practical problems associated with the proposal for citizen standing in constitutional cases suggested here. ${ }^{405}$

Therefore, both the conceptual structure and an appropriate proce-

whether the named plaintiffs can present a strong case on behalf of the entire class, Mack v. General Elec. Co., 329 F. Supp. 72, 76 (E.D. Pa. 1971), and whether the attorneys representing the class will vigorously pursue the action. Mersay v. First Republic Corp. of America, 43 F.R.D. 465, 469 (S.D.N.Y. 1968). Counsel must be qualified, experienced and adequate to conduct the litigation. Eisen v. Carlisle \& Jacquelin, 391 F.2d 555, 562 (2d Cir. 1968), rev'd on other grounds, 417 U.S. 156 (1974). The litigants must not be involved in collusive litigation, nor may named plaintiffs have interests antagonistic to those of the rest of the class. The named plaintiffs' interests must be coextensive with those of the remainder of the class. Id.; Weiss v. Tenney Corp., 47 F.R.D. 283, 290 (S.D.N.Y. 1969). Finally, the court must be satisfied that the named plaintiffs will protect the due process rights of absent class members. Eisen, 391 F.2d at 562.

401. See, e.g., Green v. Carlson, 653 F.2d 1022 (5th Cir. 1981) (per curiam), cert. denied, 454 U.S. 944 (1982); In re Folding Carton Antitrust Litig., 88 F.R.D. 211 (N.D. Ill. 1980); Tomkin v. Kaysen, 69 F.R.D. 541 (S.D.N.Y. 1976).

402. "As soon as practicable after the commencement of an action brought as a class action, the court shall determine by order whether it is to be so maintained." FED. R. C1V. P. 23(c)(1).

403. The mere pendency of a class action does not preciude parallel individual actions by class members. 3B J. Moore \& J. Kennedy, Moore's Federal Practice $\{23.92$ (2d ed. 1984). Nevertheless, "a court having in personam jurisdiction over a class suit [under Rule 23(b)(1) or (b)(2)] should have the power to enjoin competing actions that are vexatlous and oppressive." Id. (footnote omitted). For the government to have to litigate the same constitutional question repeatedly is oppressive, hence sound policy dictates the availability of injunctive relief.

Moreover, if a central index of citizen standing cases were established, all other courts would be able to stay duplicative suits pending judgment in the class action, thus avoiding judicial ineficiency. See, e.g. , Blinder, Robinson \& Co. v. SEC, 692 F.2d 102, 106 (10th Cir. 1982); Leisner v. New York Tel. Co., 358 F. Supp. 359 (S.D.N.Y. 1973).

404. See Hohmann v. Packard Instrument Co., 399 F.2d 711, 715 (7th Cir. 1968); Kainz v. Anheuser-Busch, Inc., 194 F.2d 737, 740 (7th Cir.), cert. denied, 344 U.S. 820 (1952).

405. The other requirements of Rule 23 are easily satisfied by any case of the type described here. When the citizenry is the plaintiff class, the numerosity requirement of Rule $23(\mathrm{a})(1)$ is satisfied. In addition, the constitutionality of a government action is a question common to the class, as 
dural device exist to permit recognition of a new type of standing in certain constitutional cases. The availability of citizen standing would have changed the results in some, but not all, of the standing cases from the 1970's. ${ }^{406}$ Sierra Club v. Morton ${ }^{407}$ provides an interesting example of how the limited citizen-standing theory would work. If one regards dim-

required by Rule 23(a)(2). The other two criteria of Rule 23(a) have already been discussed. See supra notes 399-401 and accompanying text.

With regard to Rule 23(b), citizen-standing actions would be maintainable under subsections $(1)(A),(1)(B)$ or (2). With respect to Rule 23(b)(1)(A), separate individual actions against a single government action or policy alleged to be unconstitutional could certainly result in inconsistent judicial interpretations establishing wholly incompatible standards of conduct for the government. Moreover, judgments in individual cases would have stare decisis value for future litigation and thus, within the meaning of Rule $23(\mathrm{~b})(1)(B)$, would tend to conclude the interests of other individuals not party to the action.

As for Rule 23(b)(2), an unconstitutional government act or policy that by its nature is incapable of producing individuated injury-in-fact, see supra notes 388-92, 396-97 and accompanying text, clearly constitutes an act generally applicable to the citizen class. In such cases, injunctive or declaratory relief is, as a practical matter, the only appropriate remedy. The courts have interpreted the rule to require that "the party opposing the class has acted either in a consistent manner toward members of the class . . . or has established a regulatory scheme common to all class members." 7A C. WRIGHT \& A. MILLER, supra note 399, § 1775, at 19-20 (footnote omitted). Thus, Rule 23(b)(2) is the section best designed for management of the type of class action proposed here.

In recent years, the Supreme Court has restricted the use of the class action device to some extent. In Zahn v. Interuational Paper Co., 414 U.S. 291 (1973), the Court held that in a diversity case, each member of the class (named or unnamed) must satisfy the jurisdictional amount requirement of 28 U.S.C. $\S 1332$ (1982). Thus, the plaintiffs' claims may not be aggregated to satisfy the amount-in-controversy requirement. Accordingly, Zahn makes it more difficult for persons with small individual claims to pursue them as a class in the federal courts.

In Eisen v. Carlisle \& Jacquelin, 417 U.S. 156 (1974), the Court ruled that each class member whose name and address was readily ascertainable had to be individually notified of the action's pendency pursuant to FED. R. CIV. P. 23 (c)(2). The Court also held that the proponent of the class was required to bear the entire cost of the notification. Eisen thus erects some substantial barriers to individuals' ability to undertake class action litigation.

Finally, Coopers \& Lybrand v. Livesay, 437 U.S. 463 (1978), sharply restricted the appealability of orders denying class certification, finding them inappropriate bases for interlocutory appeals. At the same time, the Court acknowledged that denial of certification might well be the death knell of such litigation because the individual plaintiff would find it uneconomical to pursue litigation in the absence of class certification. Id. at 469-71. Nonetheless, the Court declined to permit interlocutory appeals despite the potential "incremental benefit" in situations where litigation would be ended by denial of class action certification. Id. at 473 .

The factor which unites these cases and distinguishes them from the type of public action proposed here is that they are all actions brought pursuant to FED. R. CIV. P. 23(b)(3). Such actions are characterized by the separable individual interests of the class members; typically such actions seek money damages which may vary according to the individual's involvement in the controversy. It is for this reason that the Court has strictly interpreted the requirement of FED. R. CrV. P. 23(c)(2) that individual notice be given to each member of the (b)(3) class if practicable. Eisen v. Carlisle \& Jacquelin, 417 U.S. 156 (1974). The public actions supported by this Article, however, would be certified under FED. R. CIV. P. 23(b)(1) or (b)(2) and by definition do not involve injuries differentiable according to class member. Hence, there is no individualized interest allocable to absent class members. Recent Supreme Court cases simply do not address such actions.

406. See supra Part II, Section $A$.

407. 405 U.S. 727 (1972); see supra notes $110-16$ and accompanying text. 
inution of one's enjoyment of the environment as an injury-in-fact, ${ }^{408}$ then the result of Sierra Club would not change. Because individualized injury-in-fact would be possible, citizen standing would not be available. ${ }^{409}$

On the other hand, both United States v. Richardson 410 and Schlesinger v. Reservists Committee to Stop the War ${ }^{411}$ would be decided differently under a doctrine of citizen standing. In Richardson, the Court denied standing precisely because the plaintiff had failed to allege an interest distinguishable from that of the public generally, ${ }^{412}$ a finding echoed by the Schlesinger majority. ${ }^{413}$ The concept of citizen standing urged here would seize upon that generalized public interest as a reason to find standing, not a reason to deny it. Without recognition of such a collective right to lawful government behavior, and standing to insist upon it, some provisions of the Constitution are unenforceable, deadletter law. Similarly, the result in Valley Forge Christian College $v$. Americans United for Separation of Church and State, Inc. ${ }^{414}$ would be different. A broader standing doctrine, recognizing a collective "right to a particular kind of Government conduct, which the Government has violated by acting differently," ${ }^{415}$ would make the alleged constitutional abuse in Valley Forge subject to judicial review, precisely in order to vindicate society's generalized, but nonetheless fundamental, interest in government behavior consistent with its trust.

Finally, there remains the question of the nexus requirement. To the extent that it reflects the idea that the governmental action must not only harm the plaintiff, but must also violate some duty owed to him, ${ }^{416}$ then the recognition of the government's duty to act constitutionally as a duty owed to all citizens would satisfy the nexus requirement. That duty is breached whenever government violates the Constitution, and the nexus requirement is automatically satisfied under the collective-right citizen-standing proposal advanced here. To the extent that the nexus requirement is, in Professor Tribe's words, "an attempt to reduce the risk

408. See United States v. SCRAP, 412 U.S. 669 (1973); see supra notes $238-42$ and accompanying text.

409. If, however, the Supreme Court were to reverse its view of environmental damage expressed in SCRAP, declaring it insufficient to give rise to individual injury-in-fact, then invocation of the citizen-standing doctrine would be appropriate. In that case, the result of Sierra Club would be reversed by the new standing concept.

410. 418 U.S. 166 (1974).

411. 418 U.S. 208 (1974).

412. See supra notes $122-28$ and accompanying text.

413. See supra notes $133-42$ and accompanying text.

414. 454 U.S. 464 (1982); see supra notes 193-203 and accompanying text.

415. Valley Forge, 454 U.S. at 483.

416. See Jaffe, Standing Again, 84 HARv. L. Rev. 633, 636 (1971). See generally L. TRibE, supra note $8, \S 3-22$, at 98 . 
that federal judges will unintentionally divert the central thrust of constitutional and statutory policies by allowing 'officious intermeddlers' to invoke federal claims under provisions designed to benefit persons who may be entirely satisfied with the action challenged," 417 then the requirement is unnecessary under this new concept of standing. If the "intermeddler" can show injury-in-fact, then he should be entitled to invoke the judicial power. If he cannot make such a showing, then he is without standing unless no one else could suffer injury-in-fact either. The fact that some citizens may be satisfied with or unperturbed by the government action should not be a bar to standing; no one has the right to enjoy the perceived benefits of illegal government action.

In short, the nexus requirement diverts attention from the public's collective interest in having its government operate with the consent of the governed. On a day-to-day basis, that consent is manifest in the Constitution, statutes, and other regulations-the rules for conduct of government. Perhaps that is why the Court so sharply restricted the nexus requirement in Duke Power Co. v. Carolina Environmental Study Group, Inc. ${ }^{418}$ declaring its inapplicability except in taxpayer suits. ${ }^{419}$ Professor Tribe has suggested that even in taxpayer suits the requirement be abandoned because it is "misguided," "unnecessary," and "unwarranted."420 This Article supports that suggestion, but for an additional reason. Taxpayer standing was suggested, though repudiated, in Frothingham $v$. Mellon ${ }^{421}$ and later adopted in Flast v. Cohen ${ }^{422}$ to deal with a class of cases in which there could be no injury-in-fact under traditional doctrine. Citizen standing as suggested here, with appropriate recognition of the collective rights under the Constitution, would render taxpayer standing superfluous. Moreover, because the nexus requirement invariably operates, when applied, to foreclose standing in cases in which the collective interest of society clearly calls for the availability of judicial intervention, it is inconsistent with our Lockean foundation. The nexus requirement must be abandoned because it forecloses needed judicial review, not merely because, as Professor Tribe argues, ${ }^{423}$ it functions poorly as an empirical matter.

\section{CONCLUSION}

This Article has proposed a bifurcated standing doctrine in constitutional cases. In cases in which the challenged governmental action can

417. L. TRIBE, supra note $8, \S 3-22$, at 99 .

418. 438 U.S. 59 (1978).

419. Id. at 78-79; see supra notes 249-53 and accompanying text.

420. L. TR1BE, supra note 8, at Supp. 12 (1979).

421. 262 U.S. $447,486-88$ (1923).

422. 392 U.S. 83 (1968).

423. See L. TRIBE, supra note 8, §§ 3-26, 3-27. 
cause individualized injury-in-fact, the collective interest in lawful government behavior is sufficiently protected if enforcement is left to the individuals directly suffering the harm. But in cases where the assertedly unlawful action cannot give rise to individual injury, the collective interest can only be adequately protected if individuals are given standing to represent the public interest. The public, the collective body, has a stake in the outcome whenever the issue is whether government has violated its charter. Each person in our society is one of the settlors and beneficiaries of the trust which is civil government under the Lockean model. When the trustee violates the trust, each person is aggrieved. A standing doctrine consistent with the political philosophy so important to our constitutional system cannot fail to permit judicial challenge when the trust is broken. 